\title{
Large fluxes and rapid turnover of mineral-associated carbon across topographic gradients in a humid tropical forest: insights from paired ${ }^{14} \mathrm{C}$ analysis
}

\author{
S. J Hall ${ }^{1, *}$, G. McNicol ${ }^{1}$, T. Natake ${ }^{1}$, and W. L. Silver ${ }^{1}$ \\ ${ }^{1}$ Department of Environmental Science, Policy, and Management, University of California-Berkeley, Berkeley, USA \\ *now at: Global Change and Sustainability Center, University of Utah, Salt Lake City, USA
}

Correspondence to: S. J. Hall (steven.j.hall@utah.edu)

Received: 3 November 2014 - Published in Biogeosciences Discuss.: 16 January 2015

Revised: 5 April 2015 - Accepted: 7 April 2015 - Published: 29 April 2015

\begin{abstract}
It has been proposed that the large soil carbon (C) stocks of humid tropical forests result predominantly from $\mathrm{C}$ stabilization by reactive minerals, whereas oxygen $\left(\mathrm{O}_{2}\right)$ limitation of decomposition has received much less attention. We examined the importance of these factors in explaining patterns of $\mathrm{C}$ stocks and turnover in the Luquillo Experimental Forest, Puerto Rico, using radiocarbon $\left({ }^{14} \mathrm{C}\right)$ measurements of contemporary and archived samples. Samples from ridge, slope, and valley positions spanned three soil orders (Ultisol, Oxisol, Inceptisol) representative of humid tropical forests, and differed in texture, reactive metal content, $\mathrm{O}_{2}$ availability, and root biomass. Mineral-associated $\mathrm{C}$ comprised the large majority $(87 \pm 2 \%, n=30)$ of total soil C. Turnover of most mineral-associated C $(66 \pm 2 \%)$ was rapid (11 to 26 years; mean and SE: $18 \pm 3$ years) in 25 of 30 soil samples across surface horizons $(0-10$ and 10 $20 \mathrm{~cm}$ depths) and all topographic positions, independent of variation in reactive metal concentrations and clay content. Passive $\mathrm{C}$ with centennial-millennial turnover was typically much less abundant $(34 \pm 3 \%)$, even at $10-20 \mathrm{~cm}$ depths. Carbon turnover times and concentrations significantly increased with concentrations of reduced iron (Fe(II)) across all samples, suggesting that $\mathrm{O}_{2}$ availability may have limited the decomposition of mineral-associated $\mathrm{C}$ over decadal scales. Steady-state inputs of mineral-associated $\mathrm{C}$ were statistically similar among the three topographic positions, and could represent $10-25 \%$ of annual litter production. Observed trends in mineral-associated $\Delta^{14} \mathrm{C}$ over time could not be fit using the single-pool model used in many other studies, which generated contradictory relationships between
\end{abstract}

turnover and $\Delta^{14} \mathrm{C}$ as compared with a more realistic twopool model. The large $\mathrm{C}$ fluxes in surface and near-surface soils documented here are supported by findings from paired ${ }^{14} \mathrm{C}$ studies in other types of ecosystems, and suggest that most mineral-associated $\mathrm{C}$ cycles relatively rapidly (decadal scales) across ecosystems that span a broad range of state factors.

\section{Introduction}

Humid tropical forest soils represent a large terrestrial C reservoir ( $\sim 500 \mathrm{Pg}$; Jobbagy and Jackson, 2000$)$ with the potential to exert important feedbacks on global climate change, yet much remains unknown about the biogeochemical mechanisms underlying their $\mathrm{C}$ dynamics. Patterns and controls on plant litter decomposition in tropical ecosystems have been well documented in recent years (e.g., Cusack et al., 2009; Powers et al., 2009), but the turnover dynamics of tropical soil organic $\mathrm{C}$ have received less attention (Trumbore et al., 1995; Torn et al., 1997; Telles et al., 2003; MarinSpiotta et al., 2008; Giardina et al., 2014). The majority of organic matter (56-95\%) in humid tropical forests spanning a broad range of soil types has been shown to be associated with mineral particles (Trumbore et al., 1995; de Camargo et al., 1999; Telles et al., 2003; Marin-Spiotta et al., 2009; Cusack et al., 2011; Giardina et al., 2014). Previous work has used radiocarbon $\left({ }^{14} \mathrm{C}\right)$ modeling to demonstrate that turnover times of mineral-associated $\mathrm{C}$ pools can vary by several orders of magnitude - from decades to millennia 
- within and among humid tropical soils (Trumbore et al., 1995; Torn et al., 1997; Telles et al., 2003). Nevertheless, relatively few studies have described the dynamics of mineralassociated $\mathrm{C}$ turnover in natural humid tropical forests, particularly in relation to proposed biogeochemical mechanisms of $\mathrm{C}$ stabilization. Constraining the turnover times of surface soil $\mathrm{C}$ pools and their biogeochemical drivers in humid tropical soils remains an important research challenge given their intimate couplings with plant productivity and potentially rapid responses to climate change.

Much of the recent work on soil organic matter stabilization has focused on the importance of reactive metals and short-range-order minerals in protecting $\mathrm{C}$ via sorption and precipitation. Concentrations of iron ( $\mathrm{Fe}$ ) and aluminum (Al) in various soil extractions often correlate strongly with spatial variation in soil C stocks (Torn et al., 1997; Baldock and Skjemstad, 2000; Powers and Schlesinger, 2002; Kleber et al., 2005; Kramer et al., 2012). Although positive relationships between reactive $\mathrm{Fe}$ and $\mathrm{Al}$ and $\mathrm{C}$ stocks of mineral soils occur across a broad range of ecosystems, there have been fewer tests of their relationships with $\mathrm{C}$ turnover rates (Sollins et al., 2009). This distinction is important, because positive relationships between reactive metals and $\mathrm{C}$ stocks do not provide information regarding the dynamics of these $\mathrm{C}$ pools or the temporal scale of stabilization. Carbon turnover rates increased strongly with short-range-order mineral content across gradients of precipitation and soil age in allophane-rich tropical Andisols (Torn et al., 1997; Giardina et al., 2014), and increased with reactive $\mathrm{Al}$ content across a sequence of temperate Mollisols, Alfisols, and Inceptisols (Masiello et al., 2004). However, the relative impact of reactive $\mathrm{Fe}$ and $\mathrm{Al}$ on mineral-associated $\mathrm{C}$ turnover has received less attention in highly weathered soils (Ultisols, Oxisols) that are prevalent across humid tropical forests at a global scale. The content and composition of silicate clay minerals are also likely to contribute to soil $\mathrm{C}$ stabilization in many tropical ecosystems (Feller and Beare, 1997), although their impact on $\mathrm{C}$ turnover times in these soils remains unclear.

In addition to reactive metals and minerals, oxygen $\left(\mathrm{O}_{2}\right)$ availability and redox dynamics can also influence $\mathrm{C}$ dynamics in humid ecosystems, where anaerobic microsites are especially prevalent in surface soils. All else being equal, rates of organic matter decomposition typically decline under sustained anaerobic conditions (Ponnamperuma, 1972). Recent work has demonstrated high spatial and temporal variation in $\mathrm{O}_{2}$ availability in surface soils of humid tropical forests, and the concomitant importance of anaerobic metabolic processes such as dissimilatory Fe reduction in maintaining high rates of soil respiration (Silver et al., 1999; Schuur et al., 2001; Dubinsky et al., 2010; Liptzin et al., 2011; Hall et al., 2013). Soil C stocks increased with decreasing redox potential across a Hawaiian rainfall gradient even as net primary productivity declined, suggesting that reducing conditions constrained decomposition and promoted organic matter accumulation at the landscape scale (Schuur et al., 2001).
At smaller spatial scales ranging from topographic catenas to soil microsites, variation in $\mathrm{O}_{2}$ availability and reducing conditions could also have important impacts on rates of soil C cycling.

Radiocarbon analysis is a powerful method for modeling the turnover times of slow-cycling $\mathrm{C}$ pools, such as those associated with mineral surfaces, which are generally thought to cycle over scales of many decades to millennia. However, a paucity of replicated ${ }^{14} \mathrm{C}$ measurements in many studies has often prevented statistical examination of relationships between turnover times and proposed $\mathrm{C}$ stabilization mechanisms. Furthermore, many recent ${ }^{14} \mathrm{C}$ studies have used turnover models assuming that operationally defined organic matter pools (separated by physical or chemical fractionation) had homogeneous turnover rates. Several studies have demonstrated that operationally defined $\mathrm{C}$ fractions (e.g., free light, aggregate-occluded light, and mineral-associated) seldom represent pools with uniform turnover, and the inclusion of multiple pools with distinct turnover times within measured fractions is often necessary to generate realistic model results (Trumbore et al., 1995; von Lützow et al., 2007; Baisden et al., 2013; Torn et al., 2013). Using multiple ${ }^{14} \mathrm{C}$ measurements over time provides a valuable method for constraining the turnover of multiple pools within a single measured fraction (Trumbore et al., 1996; Koarashi et al., 2012; Baisden et al., 2013), particularly in humid tropical ecosystems that exhibit relatively rapid $\mathrm{C}$ turnover (Telles et al., 2003).

Here, we assessed the relative importance of several proposed $\mathrm{C}$ stabilization mechanisms (reactive metal content, soil texture, and proxies for reducing conditions) in explaining patterns of mineral-associated $\mathrm{C}$ concentrations, stocks, and turnover, using ${ }^{14} \mathrm{C}$ measurements and modeling of density-fractionated samples. We intensively sampled soils across a topographic catena spanning three soil orders (an Ultisol, Oxisol, and Inceptisol) typical of humid tropical forest ecosystems (McDowell et al., 2012). Samples represented a range of soil geochemical characteristics and $\mathrm{O}_{2}$ dynamics in close spatial proximity (tens of meters) (Silver et al., 1999). Our sampling strategy captured relatively large differences in soil biogeochemical characteristics while controlling for temperature, a potentially important influence on the turnover of decadal-cycling C (Townsend et al., 1995). To provide a more rigorous interpretation of our contemporary soil ${ }^{14} \mathrm{C}$ data, we constrained models of $\mathrm{C}$ turnover with ${ }^{14} \mathrm{C}$ measurements from archived 1988 samples from the same site. Finally, to illustrate the importance of considering multiple pools and ${ }^{14} \mathrm{C}$ time points for fitting $\mathrm{C}$ turnover models to data, we compared modeled turnover times of mineralassociated $\mathrm{C}$ between a simple one-pool model commonly used in the current literature and a two-pool model constrained by data from archived samples. 


\section{Methods}

\subsection{Site description}

We sampled ridge, slope, and valley topographic positions along a hillslope catena in the Bisley Watershed of the Luquillo Experimental Forest, Puerto Rico, an NSF-funded Long Term Ecological Research and Critical Zone Observatory site. Our sites $\left(250 \mathrm{~m}\right.$ a.s.l.; $\left.18.3157^{\circ} \mathrm{N}, 65.7487^{\circ} \mathrm{W}\right)$ support a lower montane tabonuco (Dacryodes excelsa) forest with a mean annual temperature of $23^{\circ} \mathrm{C}$. Annual precipitation averaged $3800 \mathrm{~mm} \mathrm{yr}^{-1}$ and varied between 2600 and $5800 \mathrm{~mm} \mathrm{yr}^{-1}$ from 1989 to 2011 (Scatena et al., unpublished data); see McDowell et al. (2012) for a detailed site description. Soils formed from volcaniclastic sedimentary rocks derived from andesitic to basaltic material, and catena positions represent three different orders in the USDA taxonomy (Soil Survey Staff, 2002). Ridges are dominantly Ultisols (Typic Haplohumults), slopes are Oxisols (Inceptic and Aquic Hapludox), and valleys are Inceptisols (Typic Epiaquepts). Catena positions differed in surface soil $\mathrm{O}_{2}$ concentrations measured at $10 \mathrm{~cm}$ depth over several years (Silver et al., 1999). Mean $\mathrm{O}_{2}$ concentrations decreased from ridges to slopes to riparian valleys $\left(19,16\right.$, and $10 \% \mathrm{O}_{2}$, respectively), with increasing temporal variability such that valley soils frequently experienced low $\mathrm{O}_{2}(\leq 3 \%)$. Anaerobic microsites are present in all topographic positions, indicated by periodic methane emissions (Silver et al., 1999). Given that iron oxides represent the most abundant anaerobic terminal electron acceptor in these soils (Hall et al., 2013) we used measurements of $\mathrm{Fe}$ (II) to provide an index of reducing conditions at the scale of individual soil samples. We acknowledge that soil $\mathrm{Fe}$ (II) concentrations constitute a one-time measurement in a dynamic redox environment, but indices of $\mathrm{O}_{2}$ availability and other redox reactions tended to vary consistently with $\mathrm{Fe}$ (II) concentrations among plots and over time (Hall et al., 2013).

\subsection{Soil sampling and analysis}

We dug a soil pit in each catena position to establish relationships between soil depth and horizons. Mineral soil A horizons spanned depths of $0-10,0-9$, and $0-10 \mathrm{~cm}$ in the ridge, slope, and valley, whereas B1 horizons were at depths of 10-22, 9-25, and 10-20 cm, respectively. Visual inspection of soil cores showed that A horizon depths were reasonably consistent among samples, but total soil depth varied among plots and occasionally did not exceed $20 \mathrm{~cm}$ in the riparian valley (due to the sporadic presence of buried boulders). We thus sampled soils at depths of 0-10 and $10-20 \mathrm{~cm}$, which contain the large majority of roots and organic matter in this ecosystem (Silver and Vogt, 1993).

We established five $0.25 \mathrm{~m}^{2}$ plots in each topographic position (ridge, slope, and valley) for a total of 15 plots in the same field sites previously examined by Silver et al. (1999).
Plots were randomly placed within 5-10 $\mathrm{m}$ intervals along a $50 \mathrm{~m}$ linear transect. On the slope position, the slopes of individual plots varied between 25 and $40^{\circ}$. Surface organic horizons were usually sparse, and any $\mathrm{O}$ horizon material was removed prior to coring. In each plot and depth increment (total $n=30$ ), we collected a total of four replicate $6 \mathrm{~cm}$ diameter soil cores. Two cores from each plot were sampled in July 2011 to determine bulk density and fine root biomass, and two additional cores were sampled in February 2012 for $\mathrm{C}$ density fractionation and chemical analysis.

The cores for chemical analyses were immediately homogenized in the field, and separate subsamples extracted in $0.5 \mathrm{M}$ hydrochloric acid $(\mathrm{HCl})$ and $0.2 \mathrm{M}$ sodium citrate/0.05 $\mathrm{M}$ ascorbic acid solutions within 1-2 min of sampling. The low $\mathrm{pH}$ of the $\mathrm{HCl}$ extraction inhibits oxidation of $\mathrm{Fe}(\mathrm{II})$. Soil subsamples ( $\mathrm{g}$ dry mass equivalent) were immersed in a $1: 10$ ratio with $\mathrm{HCl}$, vortexed, shaken for $1 \mathrm{~h}$, and filtered to $0.22 \mu \mathrm{m}$. Concentrations of $\mathrm{Fe}$ (II) were measured using a colorimetric ferrozine assay and corrected for Fe(III) interference (Viollier et al., 2000). We used Fe(II) concentrations as an index of reducing conditions at the scale of soil samples, given that Fe reduction represents the dominant anaerobic respiratory process in this system (Dubinsky et al., 2010), and that $\mathrm{Fe}(\mathrm{II})$ readily oxidizes in the presence of $\mathrm{O}_{2}$. Separate subsamples were extracted in the field with sodium citrate-ascorbate solution (Reyes and Torrent, $1997)$ to provide an estimate of reactive iron oxides $\left(\mathrm{Fe}_{\mathrm{ca}}\right)$ and associated $\mathrm{Al}\left(\mathrm{Al}_{\mathrm{ca}}\right)$ in short-range-order minerals and organic fractions. Short-range-order Fe and organo-Fe complexes are analytically indistinguishable in chemical extractions, with nanoscale iron (oxy)hydroxides often dominating (Thompson et al., 2011); thus we subsequently refer to $\mathrm{Fe}_{\mathrm{ca}}$ as "reactive". Aluminum is not redox-active in soils but frequently substitutes in Fe minerals, and various aluminum (oxy)hydroxide species and monomeric $\mathrm{Al}$ also associate with organic compounds. In the absence of detailed $\mathrm{Al}$ speciation data, we similarly refer to $\mathrm{Al}_{\mathrm{ca}}$ as "reactive". Soil subsamples ( $1.5 \mathrm{~g}$ dry mass equivalent) were immersed in a $1: 30$ ratio with citrate/ascorbate solution, vortexed, shaken for $18 \mathrm{~h}$, and centrifuged for $10 \mathrm{~min}$ at $1500 \mathrm{rcf}$.

Field extractions likely yield the most representative patterns of reactive metal abundance due to rapid crystallization of short-range-order minerals upon drying, but we also extracted oven-dried $\left(105^{\circ} \mathrm{C}\right)$ and ground heavy density fractions (described below) with acid ammonium oxalate solution in the dark at $\mathrm{pH} 3$ to allow comparison with previous studies (e.g., Kleber et al., 2005). Drying soils leads to mineral crystallization, thus decreasing extractable metal concentrations. However, oxalate extraction of moist samples with high $\mathrm{Fe}(\mathrm{II})$ is undesirable and can promote catalytic extraction of crystalline iron oxides (Phillips et al., 1993). Subsamples $(0.5 \mathrm{~g})$ were extracted for $2 \mathrm{~h}$ in $30 \mathrm{~mL}$ of ammonium oxalate solution. For all of the above extractions, concentrations of $\mathrm{Fe}$ and $\mathrm{Al}$ were analyzed in triplicate using an inductively coupled plasma optical emission spectrometer 
(ICP-OES; Perkin Elmer Optima 5300 DV, Waltham, Massachusetts). Total $\mathrm{Fe}$ measured colorimetrically in $\mathrm{HCl}$ extractions agreed within $1 \%$ of ICP-OES measurements. Soil $\mathrm{pH}$ was measured in $1: 2$ slurries of soil and deionized water. Additional subsamples of field-moist soil from each plot were analyzed for particle size via the hydrometer method (Gee and Bauder, 1986). Samples (50 g dry mass equivalent) were passed through a $2 \mathrm{~mm}$ sieve and immersed for $16 \mathrm{~h}$ in sodium hexametaphosphate solution $\left(50 \mathrm{~g} \mathrm{~L}^{-1}\right)$ to chemically disperse aggregates, which were then physically dispersed in an electric mixer. We measured changes in soil suspension density over $24 \mathrm{~h}$ to calculate clay, sand, and silt fractions.

We assayed the two remaining replicate $6 \mathrm{~cm}$ diameter cores from each plot and depth increment for fine root biomass and bulk density, respectively. Fine roots $(<2 \mathrm{~mm}$ diameter) were separated from soil by wet sieving and separated into live and dead fractions based on visual observations of turgor and tensile strength. Roots were thoroughly washed in deionized water and dried at $65^{\circ} \mathrm{C}$. To determine bulk density from the intact cores, we carefully removed any coarse roots and rocks (which were rare) after cleaning them to retain all soil. We estimated the volume of coarse roots $>5 \mathrm{~mm}$ using a cylindrical approximation, and measured the volumetric water displacement of rocks with diameter $>2 \mathrm{~mm}$; these corrections minimally affected our bulk density measurements (mean relative change of $2 \%$ ). Soils were dried at $105^{\circ} \mathrm{C}$ to constant mass, and bulk density was calculated as dry soil mass divided by coarse root and rockcorrected sample volume.

\subsection{Soil density fractionation}

We separated soil organic matter from each plot/depth increment $(n=30)$ into three fractions based on density and occlusion: (1) a free light fraction consisting of low-density $\left(<1.85 \mathrm{~g} \mathrm{~cm}^{-3}\right)$ organic matter not contained within aggregates; (2) an occluded light fraction, comprising low-density organic matter released from aggregates following sonication; and (3) a heavy fraction with density $>1.85 \mathrm{~g} \mathrm{~cm}^{-3}$ associated with soil minerals. Soil cores for density fractionation were stored at field moisture in sealed polyethylene bags at $4{ }^{\circ} \mathrm{C}$ and analyzed within 6 months of collection. We used the same protocol to fractionate four air-dried archived samples $(0-10 \mathrm{~cm}$ increment) that were collected in 1988 from nearby slope and riparian valley plots representative of the plots sampled in 2012 (Silver et al., 1994). The samples from 1988 served as a benchmark for a two-pool ${ }^{14} \mathrm{C}$ model, and were not intended to describe ecosystem-scale spatial or temporal patterns in the $\mathrm{C}$ content of density fractions. The fractionation assay followed Swanston et al. (2005) as modified for Fe-rich soils (Marin-Spiotta et al., 2008). We passed samples ( $20 \mathrm{~g}$ dry mass equivalent) through a $4.75 \mathrm{~mm}$ sieve to remove coarse litter fragments while maintaining aggregate structure. The free light fraction was separated by flotation after immersing soils in sodium polytungstate at a density of $1.85 \mathrm{~g} \mathrm{~cm}^{-3}$. The occluded light fraction was similarly obtained after mixing and sonicating soils to disrupt aggregates, with a total energy input of $200 \mathrm{~J} \mathrm{~mL}^{-1}$. The heavy fraction consisted of the remaining mineral-associated organic matter. Mass recovery of density fractions from 2012 samples measured $100 \pm 1 \%$ (mean $\pm \mathrm{SE}$ ) of the initial soil mass; mass recovery greater than $100 \%$ may reflect residual sorption of a small amount of sodium polytungstate or heterogeneous soil moisture content of the moist soil samples. Recovery measured $95.0 \pm 0.3 \%$ for the air-dried 1988 soils. Masses of free and occluded light fractions may differ between the air-dried 1988 samples and field-moist 2012 samples due to the notable effects of air-drying on aggregate structure, but variation in sample moisture during fractionation was less likely to impact the partitioning of $\mathrm{C}$ between particulate $\mathrm{C}$ and mineral-associated fractions. Oven-dried $\left(105^{\circ} \mathrm{C}\right)$ density fractions were analyzed in duplicate for $\mathrm{C}$ concentrations and $\delta^{13} \mathrm{C}$ isotopic ratios relative to V-PDB on a Vario Micro elemental analyzer in-line with an Isoprime 100 isotope ratio mass spectrometer (Elementar, Hanau, Germany).

\subsection{Radiocarbon measurements and modeling}

We measured radiocarbon content of the 30 heavy fraction samples from 2012 and the four samples from 1988 on the Van de Graaff FN accelerator mass spectrometer at the Center for Accelerator Mass Spectrometry at Lawrence Livermore National Laboratory, Livermore, CA. Heavy C fractions were subsampled into quartz tubes which were evacuated, flame-sealed, and combusted in the presence of copper oxide and silver. Resulting $\mathrm{CO}_{2}$ was reduced to graphite on iron powder in the presence of $\mathrm{H}_{2}$ at $570{ }^{\circ} \mathrm{C}$. Corrections were applied for mass-dependent fractionation using measured $\delta^{13} \mathrm{C}$, for sample preparation background using ${ }^{14} \mathrm{C}$ free coal, and for ${ }^{14} \mathrm{C}$ decay since 1950 . We report final radiocarbon values in $\Delta^{14} \mathrm{C}$ notation with an average precision of $3 \%$ (Stuiver and Polach, 1977).

To infer temporal trends in $\Delta^{14} \mathrm{C}$, previous studies have used representative samples collected at locations within $100 \mathrm{~m}$ of one another (Trumbore et al., 1996), and over even greater distances when similarities in ecosystem state factors could be maintained (Baisden et al., 2013). However, soils display fine-scale spatial heterogeneity over scales of centimeters to meters that can potentially complicate the assessment of temporal trends. This heterogeneity precluded absolute comparisons between individual samples from 1988 and 2012, as 1988 sampling locations could not be located to that degree of resolution. Furthermore, we could only analyze four 1988 samples (two slope and two valley soils) for this study. Nevertheless, as shown in Sect. 3.2, the $\Delta^{14} \mathrm{C}$ values from our 2012 samples $(n=30)$ showed no systematic spatial variation across the catena, supporting the idea that the 1988 samples were broadly representative of the site as 
a whole. The 24-year period between sample collections allowed for sensitive detection of changes in $\Delta^{14} \mathrm{C}$ over time (Schrumpf and Kaiser, 2015).

We modeled the turnover time of mineral-associated C using a time-dependent steady-state difference equation model of soil $\Delta^{14} \mathrm{C}$ dynamics in conjunction with $\Delta^{14} \mathrm{C}$ of atmospheric $\mathrm{CO}_{2}$ (Trumbore 1993; Torn et al., 2009). We assumed that $\Delta^{14} \mathrm{C}$ of a soil organic matter pool in a given year is a function of soil $\Delta^{14} \mathrm{C}$ from the previous year minus losses from decomposition and radioactive decay, plus additions of recently fixed $\mathrm{CO}_{2}$ with atmospheric $\Delta^{14} \mathrm{C}$, represented by the following equation:

$F_{\text {soil pool }, t}^{\prime}=k F_{\text {atm }, t}^{\prime}+F_{\text {soil pool }, t-1}^{\prime}\left(1-k_{\text {soil pool }}-\lambda\right)$.

Here, $F^{\prime}$ equals $\Delta^{14} \mathrm{C} / 1000+1$ at time $t, k$ is the decomposition rate constant, and $\lambda$ is the radioactive decay constant; the subscripts atm and soil pool indicate the atmosphere and an arbitrary soil $\mathrm{C}$ pool, respectively. We used a time series of atmospheric $\Delta^{14} \mathrm{CO}_{2}$ measurements from 1511 to 1950 (Stuiver et al., 1998) and 1950 to 2009 (Hua et al., 2013) for atmospheric zone 2, which includes Puerto Rico, and assumed a $5 \%$ annual decline in atmospheric $\Delta{ }^{14} \mathrm{C}$ from 2010 to 2012 (Fig. 1). This model implies first-order decay such that the inverse of the modeled decomposition rate constant represents the mean turnover time of a soil $\mathrm{C}$ pool. We fit models with a lag of 3 years between atmospheric ${ }^{14} \mathrm{C}$ values and the corresponding ${ }^{14} \mathrm{C}$ value of soil $\mathrm{C}$ inputs to provide a conservative estimate of $\mathrm{C}$ residence in plant biomass, and also present modeling results with no time lag. In both cases, turnover times represent the combined plant-soil system. Fine roots are increasingly thought to represent a dominant source of soil C (Rasse et al., 2005). Here, a three-year lag accounted for the fact that the age of $\mathrm{C}$ in fine root tissue often varies over several years (Vargas et al., 2009), and that dead roots decompose in $<1$ year at this site (Cusack et al., 2009). We used the same time lag for the $0-10$ and $10-20 \mathrm{~cm}$ depths given that fine roots were abundant in both increments, and bioturbation by earthworms was extremely common across both depth increments at this site. Finally, the model assumed that mineral-associated $\mathrm{C}$ pools were at steady state, an assumption supported by annual soil C measurements in nearby plots over a decade that included severe storm events (Teh et al., 2009), as well as similarities in forest aboveground biomass since the late 1980s (Heartsill Scalley et al., 2010).

A single-pool model for the mineral-associated (heavy) $\mathrm{C}$ fraction could not reproduce the observed temporal trend of $\Delta^{14} \mathrm{C}$ between 1988 and 2012. Therefore, we assumed that the mineral-associated $\mathrm{C}$ fraction was the sum of two pools that cycled over different timescales: a slow pool with decadal turnover, and a passive pool with centennial to millennial turnover (Trumbore et al., 1995; Telles et al., 2003; Baisden et al., 2013).

$$
F_{\text {heavy }, t}^{\prime}=P_{\text {slow }} F_{\text {slow }, t}^{\prime}+\left(1-P_{\text {slow }}\right) F_{\text {passive }, t}^{\prime}
$$
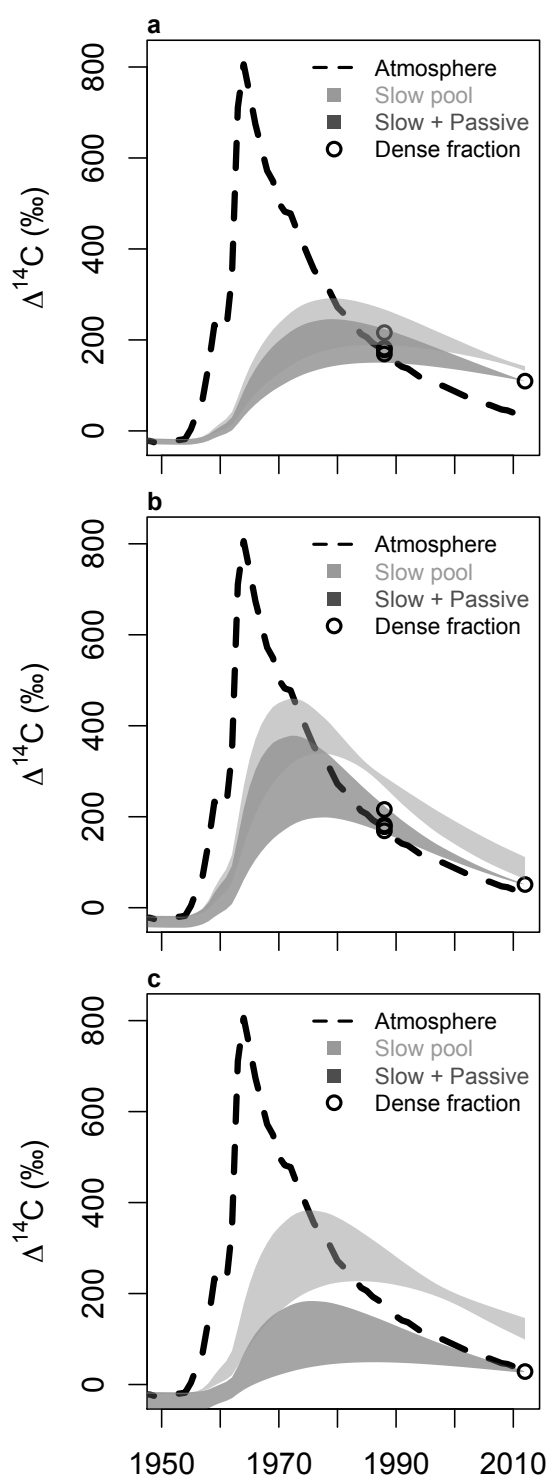

Figure 1. Modeled soil $\Delta^{14} \mathrm{C}$ over time for the slow pool (lightgrey shading) and the slow + passive pools (dark-grey shading) of mineral-associated $\mathrm{C}$. The dashed line shows atmospheric $\Delta^{14} \mathrm{C}$ for zone 2 of the Northern Hemisphere. Shaded regions represent $95 \%$ confidence intervals for $\Delta^{14} \mathrm{C}$ of a given soil sample calculated using Monte Carlo methods that varied $1988 \Delta^{14} \mathrm{C}$ and turnover time of passive C. Panels (a) and (b) show trends for individual samples where $2012 \Delta^{14} \mathrm{C}=109.4$ and $51.0 \%$, respectively, in 2012, along with four samples from 1988. Panel (c) shows trends for a sample where $2012 \Delta{ }^{14} \mathrm{C}=28.5 \%$; this and four other samples with $\Delta^{14} \mathrm{C}$ less than the 2012 atmosphere could not be realistically constrained by 1988 surface soil $\Delta^{14} \mathrm{C}$ due to a greater abundance of passive C (see Sect. 2.4 for details on how these samples were modeled).

Here, $P_{\text {slow }}$ represents the proportion of mineral-associated $\mathrm{C}$ in the slow pool. Incorporating two separate pools of organic matter in the mineral-associated fraction was necessary to fit decomposition rate constants to the observed $\Delta^{14} \mathrm{C}$ val- 
ues in 2012 and 1988, and a two-pool model is consistent with long-term observations of soil organic matter dynamics constrained by frequent $\Delta^{14} \mathrm{C}$ measurements (Baisden et al., 2013). The passive $C$ fraction contains negligible modern ${ }^{14} \mathrm{C}$ and acts to dilute the modern ${ }^{14} \mathrm{C}$ signal of the fastercycling slow $\mathrm{C}$ pool.

Thus, our model had three free parameters: turnover times of the slow and passive pools, and the proportion of mineralassociated $\mathrm{C}$ in the slow pool. We estimated two of the three parameters, the proportion of slow-pool $\mathrm{C}$ and its turnover time, with our data (soil $\Delta^{14} \mathrm{C}$ from 1988 and 2012). For the third parameter, turnover time of the passive pool, we assumed a liberal range of values (100-1000 years) during the model-fitting process (described below). Previous studies have assumed passive $\mathrm{C}$ turnover times of several hundred to 100000 years (Trumbore et al., 1995; Telles et al., 2003; Baisden et al., 2013). However, empirically determining passive $\mathrm{C}$ ages is difficult. Radiocarbon analysis of $\mathrm{C}$ remaining after acid hydrolysis has been used to define passive $\mathrm{C}$ age, yet even hydrolysis residue may contain bomb ${ }^{14} \mathrm{C}$, indicative of faster turnover times (Telles et al., 2003). Here, we assumed a relatively faster distribution of passive turnover times because these allow for realistic increases in model uncertainty. For example, allowing passive $\mathrm{C}$ turnover to increase from 1000 to 100000 years in our models had very little effect on mean slow-pool turnover $(<0.2$ years $)$, but substantially decreased the variance by decreasing the overall proportion of model runs that had shorter turnover times of the passive pool, given that shorter turnover times have more leverage on model results.

Here, we modeled the slow-pool turnover time and slowpool fraction for each 2012 sample using an approach that combined parameter estimation with sensitivity analysis, thus avoiding the assumption of a single passive pool turnover time and $1988 \Delta^{14} \mathrm{C}$ value for each 2012 sample. For example, rather than simply assuming a single value for passive pool turnover as has been done in previous studies, here we assumed that passive pool turnover varied randomly between 100 and 1000 years, and fit model parameters for each of 1000 different randomly chosen turnover times. We used a similar approach to vary the $1988 \Delta \Delta^{14} \mathrm{C}$ value assumed in each model iteration. Then, using the distribution of parameter values calculated from the 1000 model iterations for each sample, we were able to estimate mean values and their uncertainty (standard deviation). The resulting mean parameter values are subtly distinct from what we would have estimated by applying a single "best estimate" of mean 1988 $\Delta{ }^{14} \mathrm{C}$, due to the non-linear trend in atmospheric $\Delta{ }^{14} \mathrm{C}$ values.

We varied the assumed value of $1988 \Delta^{14} \mathrm{C}$ in each model realization by sampling from a normal distribution defined by the observed values (mean and standard deviation of $\Delta^{14} \mathrm{C}$ $=186 \pm 10 \%$ ) , and excluding the extreme $5 \%$ of the distribution to ensure model convergence. We acknowledge that fitting each of the 2012 samples to the same distribution of
$\Delta^{14} \mathrm{C}$ in 1988 is imperfect, as $\Delta^{14} \mathrm{C}$ values in 1988 and 2012 would likely be correlated if they could be estimated on precisely the same sample. However, the Monte Carlo approach employed here allowed us to assess the impacts of variation in assumed $1988 \Delta^{14} \mathrm{C}$ values on modeled turnover times. Varying $1988 \Delta{ }^{14} \mathrm{C}$ across the observed distribution had relatively minor impacts on modeled slow-pool turnover, affecting turnover times of each sample by an average of 3 years (Table S1 in the Supplement).

For each 2012 soil sample and randomly generated parameter set, we calculated the turnover time and proportion of slow-cycling C with Eqs. (1) and (2), adjusting $k_{\text {slow }}$ and $P_{\text {slow }}$ until modeled $\Delta^{14} \mathrm{C}$ matched the measured 2012 value and assumed 1988 value. Five 2012 samples had $\Delta^{14} \mathrm{C}$ less than the 2012 atmosphere, and slow-pool turnover times for these samples could not be realistically estimated using the available 1988 samples (Fig. 1). It is unsurprising that the four samples from 1988 did not exhibit the same degree of heterogeneity in turnover times as did the 30 samples from 2012, due to an increased probability of detecting extreme values in the larger data set. For the five samples with smaller $\Delta^{14} \mathrm{C}$ values, we made the simplifying assumption that these values were primarily caused by an increasing abundance of the passive pool, and that slow-pool turnover times were of similar magnitude as the other samples. To estimate proportions of slow vs. passive $\mathrm{C}$ in these five samples, we randomly selected 1000 slow-pool turnover times from the previously modeled distribution ( $18 \pm 3$ years) in addition to the other randomly selected parameters described above. Then, we solved for $P_{\text {slow }}$ without constraining the model to 1988 data. All modeling was conducted with $\mathrm{R}$ version 3.0.2, and free parameters were fit using the "optim" function with the Nelder-Mead method. After estimating $k_{\text {slow }}$ and $P_{\text {slow }}$, we calculated annual $\mathrm{C}$ inputs to the slow pool under steady state by dividing slow-pool C stocks by turnover times. Standard errors reported below include the sum of modeling variation and spatial variation.

\subsection{Statistical analysis}

We assessed relationships between biogeochemical variables and $\mathrm{C}$ cycling among individual samples and catena positions using linear mixed effects models fit with the lme function in R (Pinheiro et al., 2014). Interactions among topographic positions and depths were assessed by assigning a distinct factor level to each position-depth combination, with post hoc comparisons using the Tukey method. To assess topographic variation in $\mathrm{C}$ from 0 to $20 \mathrm{~cm}, \mathrm{C}$ was summed by depth increment for each plot. In addition, we fit linear mixed effects models for mineral-associated $\mathrm{C}$ concentrations and stocks in individual samples. Potential predictor variables included $\Delta^{14} \mathrm{C}$ and the other measured biogeochemical variables described above. We normalized predictor variables by mean and standard deviation to allow comparison of their relative importance (analogous to Pearson's $r$ ). Models in- 
cluded plots as potential random effects to account for any correlation between depth increments in a given plot. We selected the optimal random effect structure by comparing the Akaike information criterion (AIC) of saturated models fit using restricted maximum likelihood. Including random effects did not improve fit, so we proceeded with multiple regression. We selected fixed effects on models fit using maximum likelihood using backwards selection and AIC with a correction for small sample size, and reported models with similar goodness of fit.

\section{Results}

\subsection{Topographic patterns in soil $\mathrm{C}$ and biogeochemical variables}

Mineral-associated C comprised the dominant $\mathrm{C}$ fraction across all topographic positions, representing $90 \pm 1,89 \pm 1$, and $80 \pm 4 \%$ of total soil $\mathrm{C}$ in the ridge, slope, and valley soils, respectively (Table 1, Fig. 2, Table S1 in the Supplement). Mineral-associated $\mathrm{C}$ content (soil mass basis) in ridge $0-10 \mathrm{~cm}$ soils was 1.45 times greater $(p<0.01)$ than slopes and valleys (Fig. 2, Table 1). Mineral associated C content was also greater in surface $(0-10 \mathrm{~cm})$ than subsurface $(10-20 \mathrm{~cm})$ soils on ridges and slopes but did not differ by depth in valleys. Free light $\mathrm{C}$ content was similar among topographic positions. Valleys had significantly more occluded light $\mathrm{C}$ when considering both depth increments together, measuring 3.6 times the occluded light $\mathrm{C}$ on ridge and slope soils (Fig. 2; $p<0.05$ ). Carbon concentrations of the individual fractions generally showed similar trends with topography and depth as soil-mass-based C content (Table 1). Heavy fraction $\mathrm{C}$ concentrations were greatest in ridge surface soils, and occluded light $\mathrm{C}$ concentrations were greatest in valley soils. Heavy fraction C content was lower in the four 1988 samples than in many of the 2012 samples (Table S2 in the Supplement), but replication was insufficient to assess any temporal changes.

Paralleling the topographic patterns in mineral-associated $\mathrm{C}$, most measured biogeochemical indicators varied strongly and significantly across the catena (Table 2, Table S3 in the Supplement). Ridges supported the highest fine root biomass, which declined in the slopes and valleys. Soil $\mathrm{pH}$ was significantly more acidic $(4.6 \pm 0.0)$ in the ridge and slope samples than in the valleys $(5.2 \pm 0.1 ; p<0.0001)$, regardless of depth increment. Clay content was consistently high in ridge and slope samples $(41 \pm 3 \%)$ and significantly lower in the valley soils $(23 \pm 2 \% ; p<0.0001)$. Conversely, sand content was low in ridge and slope samples but was 2-3 times greater in the valley soils, and silt content was similar across topographic positions. Clay content increased and silt declined with depth in the ridge soils, while texture did not vary significantly with depth in the other topographic positions.
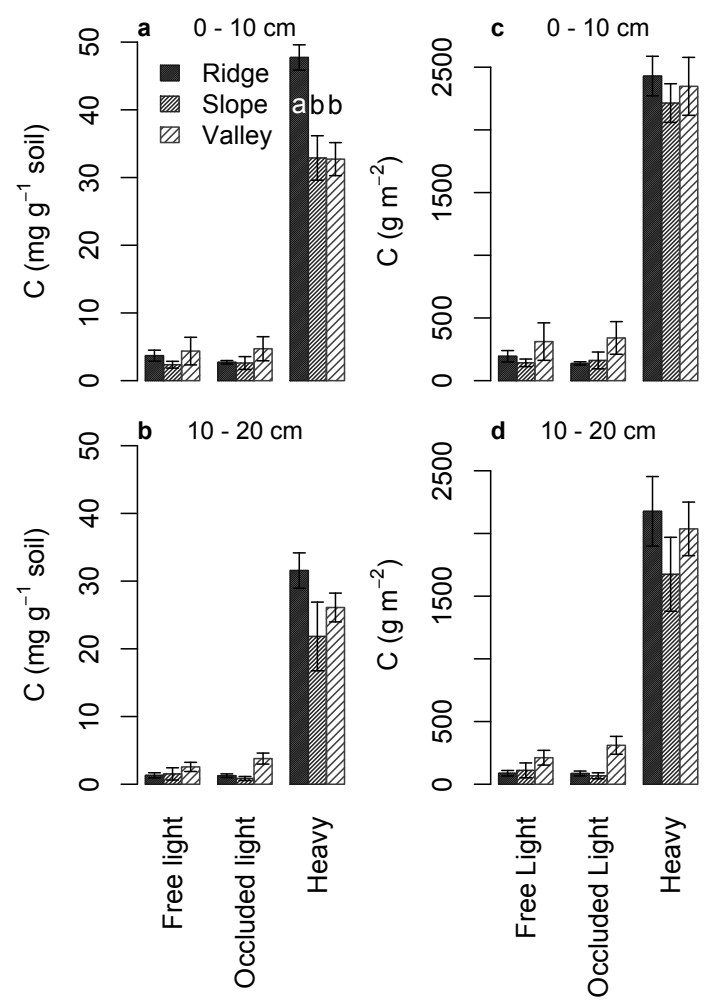

Figure 2. Carbon concentrations and stocks (mean $\pm \mathrm{SE}, n=5$ for each bar) by density fraction, catena position, and depth increment. Means with different letters are significantly different. Occluded light fractions were greatest in valleys when compared across positions, irrespective of depth.

Reactive $\mathrm{Fe}$ and $\mathrm{Al}$ showed distinct patterns among topographic positions and depths that varied by chemical extraction (Table 2). Concentrations of $\mathrm{Fe}$ and $\mathrm{Al}$ extracted in the field by citrate-ascorbate solution $\left(\mathrm{Fe}_{\mathrm{ca}}\right.$ and $\left.\mathrm{Al}_{\mathrm{ca}}\right)$ were significantly (more than 2-fold) greater in ridge than in slope or valley surface soils. Oxalate extractions of dried soil heavy fractions yielded significantly greater $\mathrm{Al}$ in ridge surface soils than most other positions/depths, but $\mathrm{Fe}_{\mathrm{ox}}$ varied little among samples. Concentrations of $\mathrm{Fe}_{\mathrm{ox}}$ and $\mathrm{Fe}(\mathrm{II})$ were the only measured biogeochemical variables that did not vary by topographic position. $\mathrm{Fe}$ (II) concentrations were variable and consistently measurable, indicative of the ubiquitous presence of reducing microsites across the plots.

Mineral-associated $\mathrm{C}$ stocks varied almost 3-fold among samples, between 1230 and $3030 \mathrm{~g} \mathrm{C} \mathrm{m}^{-2}$ (mean $2150 \pm$ 100 ) in each $10 \mathrm{~cm}$ depth increment (Table 1, Table $S 1$ in the Supplement). Summing the two $10 \mathrm{~cm}$ depth increments in each plot yielded mineral-associated C stocks of 3310 $6630 \mathrm{~g} \mathrm{C} \mathrm{m}^{-2}$ (mean $5010 \pm 290$ ) to $20 \mathrm{~cm}$ depth. Despite the large and significant differences in $\mathrm{C}$ concentrations, mass-based $\mathrm{C}$ content, and reactive $\mathrm{Fe}$ and $\mathrm{Al}$ across the catena, mineral-associated $\mathrm{C}$ stocks were statistically similar among the topographic positions (Fig. 2) due to covaria- 


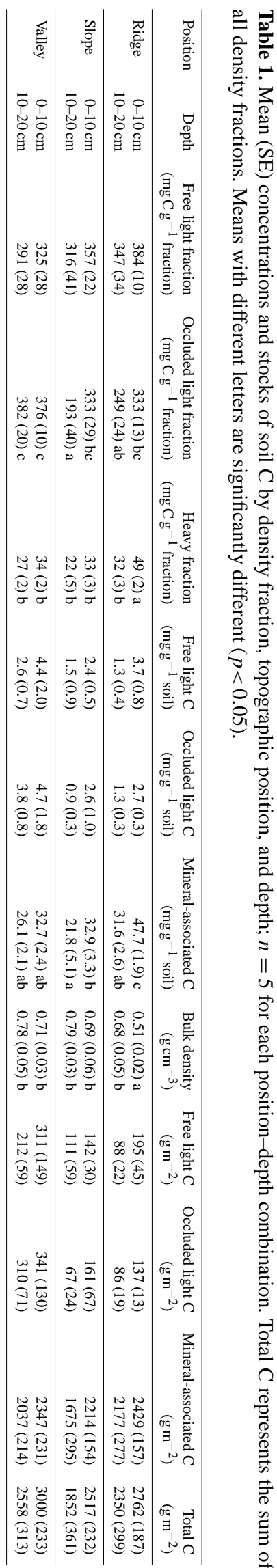

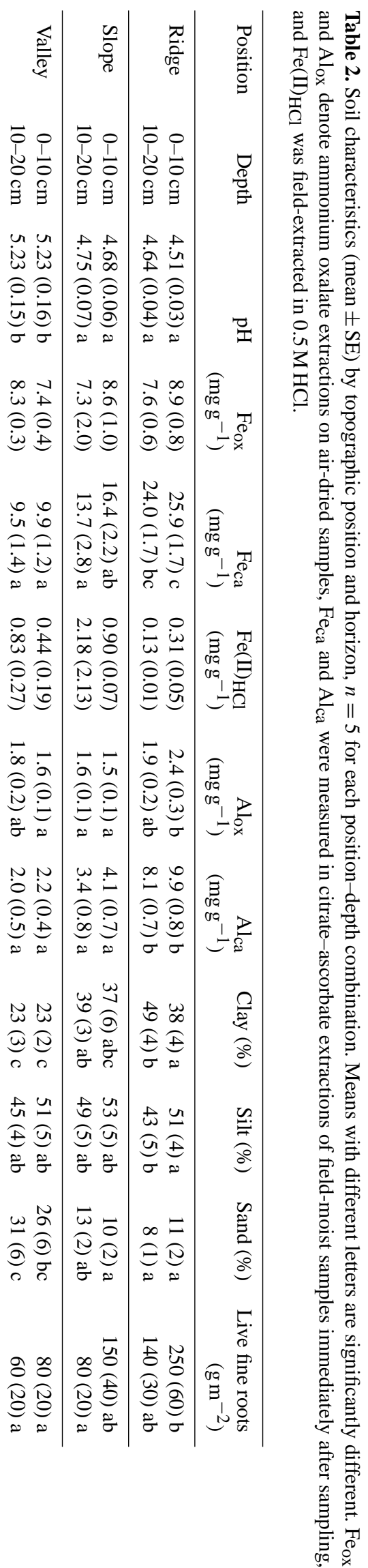

www.biogeosciences.net/12/2471/2015/ 
tion in bulk density. Bulk density was significantly lower in ridge $0-10 \mathrm{~cm}$ soils than all other positions, whereas mineralassociated $\mathrm{C}$ concentrations and mass-based $\mathrm{C}$ content were greatest in these samples $(p<0.01$; Fig. 2, Table 1). Massbased mineral-associated $\mathrm{C}$ content and bulk density also negatively covaried at the scale of individual samples $\left(R^{2}=\right.$ $0.49, p<0.0001)$.

Of the density fractions measured, only the occluded light fraction $\mathrm{C}$ stocks differed by topographic position; these were significantly greater in valleys when considering both depth increments together $(p<0.05)$. Total soil $\mathrm{C}$ stocks (sum of all three fractions in each depth increment) did not significantly differ among positions in either depth increment. Similarly, total C stocks summed to $20 \mathrm{~cm}$ in each plot $\left(\mathrm{g} \mathrm{C} \mathrm{m}^{-2}\right)$ did not differ significantly, although valleys tended to be greatest $(5558 \pm 511)$, ridges intermediate (5112 \pm 337$)$, and slopes lowest (4370 \pm 579 ; Table 1$)$.

\subsection{Patterns in $\Delta^{14} \mathrm{C}$, turnover, and $\mathrm{C}$ inputs}

The four soil samples from 1988 were enriched in ${ }^{14} \mathrm{C}$ relative to the 2012 samples, reflecting a dominance of $\mathrm{C}$ with decadal turnover in the $0-10 \mathrm{~cm}$ depth increment (Fig. 1a and b, Table 3, Table S2 in the Supplement). Figure 1 shows temporal trends in modeled $\Delta{ }^{14} \mathrm{C}$ for three representative 2012 samples. Radiocarbon content in the 2012 mineral-associated C fractions exceeded the 2012 atmosphere for most samples (25 of 30; Fig. 4, Table S2 in the Supplement), reflecting the dominance of bomb $\mathrm{C}$ inputs over the preceding decades. Radiocarbon content tended to be greatest in valley $10-20 \mathrm{~cm}$ soils and lowest in slope $10-20 \mathrm{~cm}$ soils, but differences were not significant across catena positions and depths, with the exception of slope and valley $10-20 \mathrm{~cm}$ samples (Table 3). Five slope and ridge samples had lower $\Delta^{14} \mathrm{C}$ than the 2012 atmosphere $(<30 \%)$, indicating dominance of slower-cycling $\mathrm{C}$ pools (centennial-millennial; Fig. 1c). Figure 1 shows that, in samples dominated by decadal-cycling $\mathrm{C}$, larger $\Delta{ }^{14} \mathrm{C}$ values in 2012 correspond with longer turnover times, whereas, for samples dominated by centennial-cycling $\mathrm{C}$, lower $\Delta{ }^{14} \mathrm{C}$ values in 2012 imply longer turnover times.

Mean modeled turnover times of the slow pool of mineralassociated $\mathrm{C}$ varied between 11 and 26 years, with an overall mean and SE of $18 \pm 3$ years $(n=25)$ among samples where $\Delta{ }^{14} \mathrm{C}$ exceeded the 2012 atmosphere (Fig. 1; Table S2 in the Supplement). Omitting a three-year lag between plant $\mathrm{C}$ fixation and inputs to the mineral-associated pools subtly increased the mean modeled slow-pool turnover time to $20 \pm 2$ years. Varying turnover times of the passive mineralassociated C pool and sample $\Delta^{14} \mathrm{C}$ in 1988 had relatively little impact on slow-pool turnover times and the amount of slow-pool C. The combined impact of varying passive $\mathrm{C}$ turnover and $1988 \Delta^{14} \mathrm{C}$ over 1000 model runs generated standard deviations in slow-pool turnover times between 2 and 4 years (mean $2.8 \pm 0.1$ ) for individual samples (Table S1 in the Supplement). Slow-pool turnover times and the

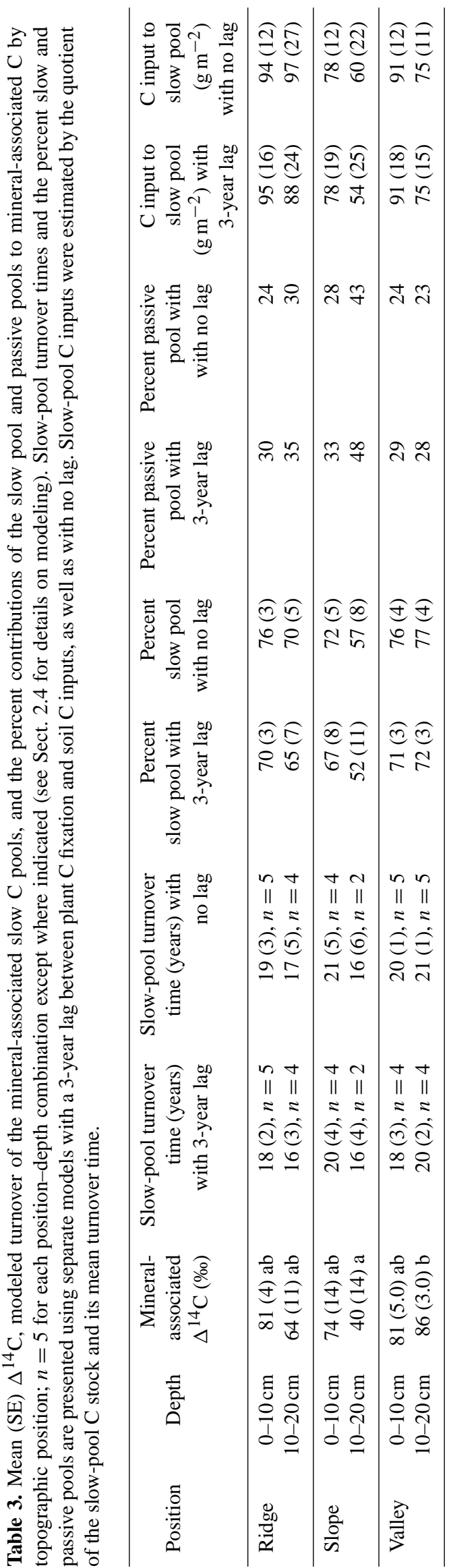

Biogeosciences, 12, 2471-2487, 2015 
amount of slow-pool C did not differ significantly among topographic positions or depth, although the modeled fraction of slow-pool C was smallest in the slope $10-20 \mathrm{~cm}$ soils, corresponding with lowest sample $\Delta^{14} \mathrm{C}$ (Table 3 ).

Slow-pool $\mathrm{C}$ greatly exceeded passive $\mathrm{C}$ in most (25 of 30) samples, whereas passive $C$ was dominant in the remainder (5) (Table S1 in the Supplement). Across all 30 samples, slow-pool $\mathrm{C}$ comprised a mean of $66 \pm 2 \%$ of the mineral-associated fraction (Table 3). Omitting a three-year lag between $\mathrm{C}$ fixation and input increased the percentage of slow-pool $\mathrm{C}$ to $71 \pm 3 \%$ of the mineral-associated fraction. Variation in other model parameters had relatively little impact on the size of the mineral-associated slow $\mathrm{C}$ pool; standard deviations of the percentage of slow-pool $\mathrm{C}$ varied between 3 and $10 \%$ for individual soil samples (mean $5.0 \pm 0.2 \%$ ). However, inputs of $\mathrm{C}$ to the slow pool required to maintain steady-state $\mathrm{C}$ stocks in each $10 \mathrm{~cm}$ depth increment varied more than 5-fold among samples (between 27 and $126 \mathrm{~g} \mathrm{C} \mathrm{m}^{2} \mathrm{yr}^{-1}$ ), with an overall mean and SE of $80 \pm$ $5 \mathrm{~g} \mathrm{C} \mathrm{m}^{2} \mathrm{yr}^{-1}$ (Table 3; Table S1 in the Supplement). When summed over both depths, slow-pool C inputs tended to be greatest on ridges, intermediate in valleys, and lowest on slopes, measuring $183 \pm 18,166 \pm 19,132 \pm 17 \mathrm{~g} \mathrm{C} \mathrm{m}^{2} \mathrm{yr}^{-1}$; these differences were not statistically significant.

The slow pool of our constrained two-pool model and the one-pool model of mineral-associated $\mathrm{C}$ turnover implied contradictory relationships (of opposite sign) between $\mathrm{C}$ turnover times and $\Delta^{14} \mathrm{C}$ (Fig. 3). Slow-pool turnover time increased with $\Delta^{14} \mathrm{C}$, whereas the overall turnover times of a single-pool model decreased with $\Delta^{14} \mathrm{C}$.

\subsection{Statistical models of $\mathrm{C}$ concentrations, stocks, and turnover}

Mineral-associated $\mathrm{C}$ concentrations (mass basis) decreased with depth, increased with $\mathrm{Al}_{\text {ca }}, \mathrm{Fe}(\mathrm{II})$, and $\mathrm{Al}_{\mathrm{Ox}}$ concentrations, and showed no relationship with $\Delta^{14} \mathrm{C}$ or modeled slow-pool turnover times (Table 4). Excluding depth as a potential variable in model selection yielded a model with similar explanatory power that included live fine root biomass. Both models explained the majority of spatial variation in mineral-associated $\mathrm{C}$ concentrations, with $R^{2}$ values of 0.88 and 0.73 , respectively. Two similar models of mineral-associated $\mathrm{C}$ stocks included (a) $\Delta^{14} \mathrm{C}$ and $\mathrm{Al}_{\mathrm{ox}}$ or (b) $\mathrm{Fe}(\mathrm{II})$ and depth, and explained less variation than models of $\mathrm{C}$ concentrations $\left(R^{2}=0.46\right.$ and 0.43 , respectively, Table 4). The optimal model for $\Delta^{14} \mathrm{C}$ and the slow-pool turnover time of the mineral-associated $\mathrm{C}$ fraction included only one variable: $\Delta^{14} \mathrm{C}$ increased with log-transformed Fe(II) concentrations ( $R^{2}=0.35, p<0.001$; Table 4, Fig. 4), as did slow-pool turnover times $\left(R^{2}=0.25, p<0.05\right.$; Table 4).

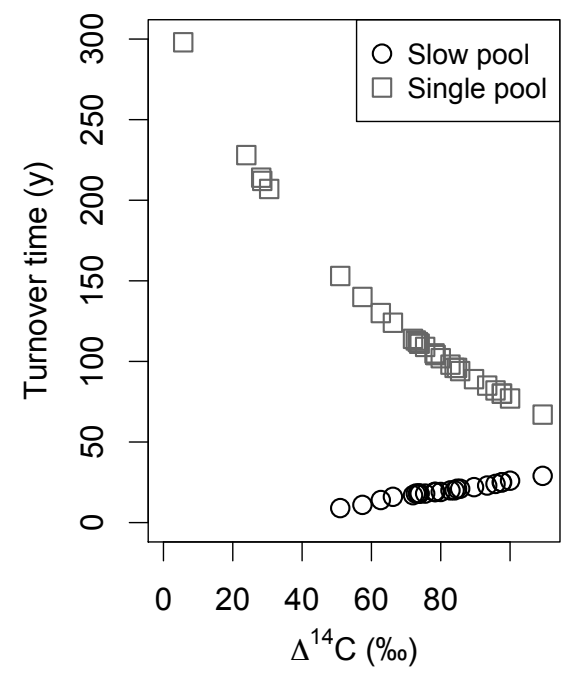

Figure 3. Relationships between $\Delta^{14} \mathrm{C}$ of the mineral-associated fraction and modeled turnover time. Circles represent the slow mineral-associated pool, which comprised most $(66 \pm 2 \%)$ of the total mineral-associated C. Squares represent a single-pool model of mineral-associated $\mathrm{C}$, which has commonly been employed in other studies but could not be fit to both our 1988 and 2012 samples.

\section{Discussion}

We examined relationships between soil $\mathrm{C}$ content, turnover of mineral-associated $\mathrm{C}$, and a suite of soil biogeochemical variables thought to affect $\mathrm{C}$ storage across topographic zones representing three different soil orders characteristic of humid tropical forests. Samples differed greatly in their concentrations of reactive $\mathrm{Fe}$ and $\mathrm{Al}$, reducing conditions (as measured by $\mathrm{Fe}(\mathrm{II})$ concentrations), and live fine root biomass, drivers that have been proposed to control soil $\mathrm{C}$ dynamics within and among ecosystems (Torn et al., 1997; Schuur et al., 2001; Powers and Schlesinger, 2002; Kleber et al., 2005). While we found strong relationships between several of these biogeochemical indices and mineralassociated $\mathrm{C}$ concentrations, they explained less variation in mineral-associated $\mathrm{C}$ stocks and turnover, which were surprisingly consistent across these disparate soils. Thus, despite the demonstrable differences in biogeochemical characteristics among topographic positions, our results implied that these soils received similar annual inputs of $\mathrm{C}$ to a slowcycling mineral-associated $\mathrm{C}$ pool.

\section{Patterns of mineral-associated $\mathrm{C}$ concentrations and stocks}

The mineral-associated "heavy" fraction comprised the vast majority of soil $\mathrm{C}$ in this ecosystem, similar to findings from other humid tropical forests (Trumbore, 1993; Marin-Spiotta et al., 2009; Cusack et al., 2011), and contrasting with many temperate forests where low-density $\mathrm{C}$ fractions are often 
Table 4. Linear models of C concentrations, stocks, and slow-pool turnover. Normalized model coefficients (SE) are analogous to Pearson's $r$. See Table 2 for variable descriptions. Models A and B represent different models with similar AIC.

\begin{tabular}{|c|c|c|}
\hline \multicolumn{3}{|c|}{$\mathrm{C}$ concentrations } \\
\hline \multirow{5}{*}{ Model A } & Depth & $-0.90(0.14)$ \\
\hline & $\mathrm{Al}_{\mathrm{ca}}$ & $0.51(0.09)$ \\
\hline & $\mathrm{Fe}(\mathrm{II})$ & $0.35(0.07)$ \\
\hline & $\mathrm{Al}_{\mathrm{OX}}$ & $0.22(0.09)$ \\
\hline & $R^{2}$ & 0.88 \\
\hline \multirow{5}{*}{ Model B } & $\mathrm{Al}_{\mathrm{ca}}$ & $0.41(0.16)$ \\
\hline & $\mathrm{Fe}(\mathrm{II})$ & $0.35(0.11)$ \\
\hline & Live fine roots & $0.27(0.14)$ \\
\hline & $\mathrm{Al}_{\mathrm{OX}}$ & $0.25(0.13)$ \\
\hline & $R^{2}$ & 0.73 \\
\hline \multicolumn{3}{|c|}{ C stocks } \\
\hline \multirow{3}{*}{ Model A } & $\Delta^{14} \mathrm{C}$ & $0.53(0.14)$ \\
\hline & $\mathrm{Al}_{\mathrm{OX}}$ & $0.36(0.14)$ \\
\hline & $R^{2}$ & 0.46 \\
\hline \multirow{3}{*}{ Model B } & $\mathrm{Fe}(\mathrm{II})$ & $0.58(0.15)$ \\
\hline & Depth & $-0.53(0.29)$ \\
\hline & $R^{2}$ & 0.43 \\
\hline \multicolumn{3}{|c|}{$\Delta^{14} \mathrm{C}$} \\
\hline & $\mathrm{Fe}(\mathrm{II})$ & $0.59(0.15)$ \\
\hline & $R^{2}$ & 0.35 \\
\hline \multicolumn{3}{|c|}{ Slow-pool turnover } \\
\hline & $\mathrm{Fe}(\mathrm{II})$ & $0.47(0.18)$ \\
\hline & $R^{2}$ & 0.25 \\
\hline
\end{tabular}

significant in mineral soils (von Lützow et al., 2007). We could explain the large majority of the variation in mineralassociated $\mathrm{C}$ concentrations across the catena with a small suite of biogeochemical drivers: concentrations of reactive $\mathrm{Al}$; $\mathrm{Fe}(\mathrm{II})$; and depth, a factor that could largely be explained by live fine root biomass. These models of $\mathrm{C}$ concentrations are consistent with previous work documenting strong and widespread relationships between reactive metals, short-range-order minerals and $\mathrm{C}$ content across disparate soils (e.g., Baldock and Skjemstad, 2000; Kleber et al., 2005; Kramer et al., 2012). However, models also reflected the likely importance of reducing microsites, as indicated by $\mathrm{Fe}(\mathrm{II})$. Reduced iron accumulation is reflective of $\mathrm{O}_{2}$ limitation, which can decrease decomposition rates by inhibiting oxidative enzymes and decreasing the ATP yield of respiration. Iron reduction can also release DOC into the soil solution and increase its bioavailability (Thompson et al., 2006), although the positive relationship shown here between Fe(II) and mineral-associated $\mathrm{C}$ content and turnover times suggests that any inhibitory effects of anaerobiosis on organic matter decomposition may predominate in these soils over

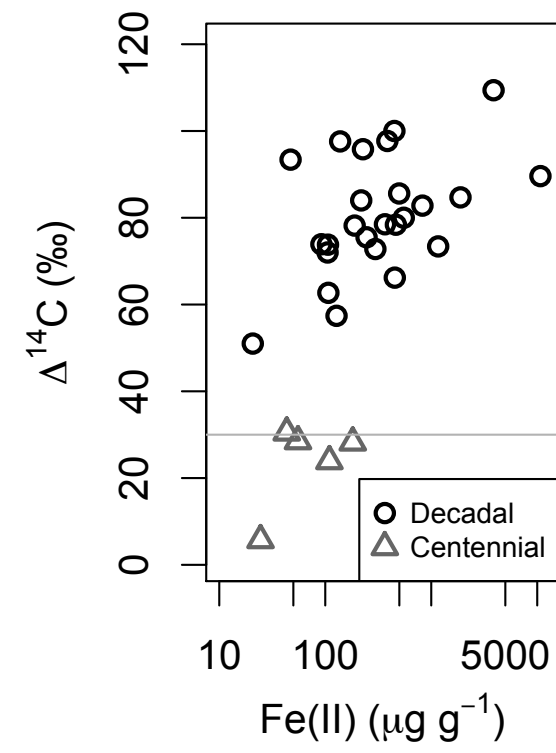

Figure 4. Soil $\Delta^{14} \mathrm{C}$ vs. Fe(II) concentrations measured in $0.5 \mathrm{M}$ $\mathrm{HCl}$ extractions conducted in the field $\left(R^{2}=0.35, p<0.001\right)$. Reduced $\mathrm{Fe}$ was the best single correlate of $\Delta^{14} \mathrm{C}$ and slow-pool turnover times; $\mathrm{Fe}$ (II) correlated positively with turnover times. Circles indicate samples with the majority of $\mathrm{C}$ in the decadal-cycling slow pool; triangles indicate samples dominated by passive $\mathrm{C}$ of centennial to millennial age. The relationship between $\Delta^{14} \mathrm{C}$ and $\mathrm{C}$ turnover was qualitatively different between these groups of samples; increased $\Delta^{14} \mathrm{C}$ implied longer turnover times for the circles, and smaller $\Delta^{14} \mathrm{C}$ implied longer turnover for the triangles. The grey horizontal line indicates the approximate $\Delta^{14} \mathrm{C}$ of the 2012 atmosphere in Northern Hemisphere zone 2.

decadal timescales. Reduced Fe is potentially vulnerable to leaching, although $\mathrm{O}_{2}$ heterogeneity promotes $\mathrm{Fe}$ oxidation and precipitation in close proximity to anaerobic microsites (Hall et al., 2013), leading to the maintenance of large pools of short-range-order Fe in this system as indicated by the soil extraction data. Depth was another effective surrogate for mineral-associated $\mathrm{C}$, which could largely be explained by increased live fine root biomass in $0-10 \mathrm{~cm}$ samples. Substituting live fine roots for depth only slightly decreased model predictive power, suggesting the influence of root $\mathrm{C}$ inputs or other covariate(s) related to live fine root biomass in increasing mineral-associated C content. Standardized regression coefficients indicated that each of these variables (reactive $\mathrm{Al}, \mathrm{Fe}(\mathrm{II})$, and live fine roots) was similarly important in explaining spatial variation in $\mathrm{C}$ concentrations. Clay content showed no relationship with soil $\mathrm{C}$, suggesting that hydrous oxides and metals were more important in stabilizing $\mathrm{C}$ than silicates in these soils, which are dominated by relatively less reactive kaolinite.

The measured biogeochemical variables were less effective in explaining patterns of surface soil $\mathrm{C}$ stocks than $\mathrm{C}$ concentrations among these samples. This may have been partially due to a strong inverse relationship between soil- 
mass-based $\mathrm{C}$ concentrations and bulk density that has been widely documented in other soils (Saini, 1966). Translocation of surface $\mathrm{C}$ to deeper (and denser) unsampled horizons could also contribute to this discrepancy.

\subsection{Patterns of mineral-associated $\mathrm{C}$ turnover}

\subsubsection{Comparisons with previous studies in tropical forests}

Despite the importance of tropical forest soils to the global C cycle, few studies have rigorously constrained the turnover rates of organic matter pools associated with mineral surfaces, which represent the bulk of soil $\mathrm{C}$ in these ecosystems. Numerous studies have exploited tropical land-use conversions characterized by shifts from $\mathrm{C} 3$ to $\mathrm{C} 4$ vegetation and concomitant changes in $\mathrm{C}$ isotopes to examine $\mathrm{C}$ turnover, yet these investigations cannot separate effects of disturbance and species change from background $\mathrm{C}$ dynamics (Ehleringer et al., 2000). Our results demonstrated consistently rapid turnover of the mineral-associated slow $\mathrm{C}$ pool (11-26 years; mean and SE: $18 \pm 3$ years), which represented the majority $(66 \pm 2 \%)$ of mineral-associated $\mathrm{C}$ in most samples. These estimates are remarkably consistent with ${ }^{14} \mathrm{C}$ derived turnover estimates by Trumbore et al. (1995) from Oxisols in seasonally dry Amazonian forests, where the slow pool of dense organic matter turned over on timescales of 10 30 years. Our estimates of slow-pool C turnover are also similar to several Hawaiian ecosystems (Townsend et al., 1995; Torn et al., 2005) but faster than those modeled in an Amazonian Oxisol in Manaus, where most C (70\%) turned over on timescales of 70 years at $10 \mathrm{~cm}$ depth (Telles et al., 2003).

\subsubsection{Trends in $\mathrm{C}$ turnover with depth}

Notably, we generally found similar $\Delta^{14} \mathrm{C}$ and turnover rates in surface $(0-10 \mathrm{~cm})$ and subsurface $(10-20 \mathrm{~cm})$ depths (corresponding with $\mathrm{A}$ and $\mathrm{B}$ horizons, respectively) across all catena positions. This finding contrasts with steep declines in decomposition rates frequently observed in relatively shallow B horizons in other ecosystems (Trumbore et al., 1995; Gaudinski et al., 2000; Telles et al., 2003; Torn et al., 2013). Inputs of surface litter and root biomass are typically thought to be lower in $\mathrm{B}$ horizons, but $\mathrm{C}$ redistribution by anecic earthworms and other soil fauna likely provides an important source of $\mathrm{C}$ inputs to the subsoil, as these organisms are extremely abundant at this site and in many other humid tropical forests (Gonzalez et al., 2006). Dissolved organic C (DOC) represents another likely source of $\mathrm{C}$ to subsurface soils, and concentrations are very low $\left(\sim 2 \mathrm{mg} \mathrm{L}^{-1}\right)$ at A-B horizon boundaries at this site (Hall et al., 2013), indicative of high sorption capacity. Five of the 30 samples had $\Delta^{14} \mathrm{C}$ lower than the 2012 atmosphere, and these also tended to have lower $\mathrm{C}$ concentrations, likely reflecting "dilution" of the slow pool by passive $\mathrm{C}$ with pre-modern $\Delta^{14} \mathrm{C}$ values. These samples may reflect recent fine-scale redistribution of surface soil and exposure of deeper soil horizons following disturbances such as small treefall gaps (scale of square meters), which are common in this forest (Scatena and Lugo, 1995). Overall, our findings of high $\Delta^{14} \mathrm{C}$ and relatively fast turnover across the two depths sampled here suggests that both surface and shallow subsurface mineralassociated organic matter may respond more rapidly to environmental change than was previously thought (de Camargo et al., 1999).

\subsubsection{Impacts of biogeochemical drivers on $\mathrm{C}$ turnover}

The overall similarities in turnover times across topographic positions despite large differences in concentrations of reactive $\mathrm{Al}, \mathrm{Fe}$, and clay content suggest that spatial variation in mineral-organic interactions may have less impact on $\mathrm{C}$ turnover rates in these highly weathered soils (Ultisols, Oxisols, and Inceptisols) than in allophane-rich Andisols, where short-range-order minerals were a dominant predictor of $\Delta^{14} \mathrm{C}$ (Torn et al., 1997). Herold et al. (2014) similarly found a positive relationship between reactive metals and $\mathrm{C}$ content, but not $\Delta{ }^{14} \mathrm{C}$, in German Luvisols and Stagnosols. Thus, strong positive relationships between soil $\mathrm{C}$ concentrations and the reactive $\mathrm{Al}$ content measured in soil extractions may reflect the importance of metal-organic associations in transient $\mathrm{C}$ accumulation rather than long-term $\mathrm{C}$ stabilization in this ecosystem. Concentrations of $\mathrm{Fe}(\mathrm{II})$ indicative of microbial $\mathrm{Fe}$ reduction were the only variable significantly correlated with $\Delta^{14} \mathrm{C}$ and turnover times. Although $\mathrm{Fe}(\mathrm{II})$ concentrations vary over time in this ecosystem in response to microsite-scale biogeochemical processes, nearby plots tended to maintain differences and rank order in reducing conditions (Hall et al., 2013), likely as a function of microtopography (i.e., concave vs. convex surfaces over scales of tens of centimeters). Thus, the variation by nearly 4 orders of magnitude in $\mathrm{Fe}$ (II) concentrations that we observed among plots likely reflects, at least to some extent, constitutive differences in reducing conditions. The positive relationship between $\mathrm{Fe}(\mathrm{II})$ and $\Delta^{14} \mathrm{C}$ may suggest that microsite $\mathrm{O}_{2}$ limitation affects slow-pool $\mathrm{C}$ turnover, possibly due to the inhibition of oxidative enzymes and/or decreased energy yield of decomposition, as discussed above. The trend towards greater $\Delta^{14} \mathrm{C}$ (implying longer turnover) in $10-20 \mathrm{~cm}$ horizons of the valley soils, which experience the lowest bulk soil $\mathrm{O}_{2}$ availability, is also supportive of this hypothesis. We found no significant differences in mineral-associated C turnover and stocks across ridge, slope, and valley positions despite variation in bulk soil $\mathrm{O}_{2}$ measured previously (Silver et al., 1999). Differences between bulk soil $\mathrm{O}_{2}$ and $\mathrm{Fe}(\mathrm{II})$ concentrations are by no means surprising, as they reflect different spatial scales of redox heterogeneity (macropore $\mathrm{O}_{2}$ content vs. soil microsites) that have long been known to exist in soils (Sexstone et al., 1985). The pattern of significantly greater occluded light $\mathrm{C}$ content in valley soils, however, may 
imply that consistently lower bulk soil $\mathrm{O}_{2}$ availability might promote the accumulation of this fraction. Berhe et al. (2012) found a similar pattern of light fraction $\mathrm{C}$ accumulation in a poorly drained valley in a Mediterranean shrub/grassland.

\subsubsection{Steady-state mineral-associated $\mathrm{C}$ inputs}

Another implication of the relatively rapid turnover of the slow-cycling $\mathrm{C}$ pool and the uniform $\mathrm{C}$ stocks across the catena is the substantial $\mathrm{C}$ input to the mineral-associated fraction required to maintain steady state. Aboveground litterfall net primary production (NPP) averages approximately $900 \mathrm{~g}_{\text {biomass }} \mathrm{m}^{-2} \mathrm{yr}^{-1}$ in this forest (Scatena et al., 1996), implying that root NPP is likely of similar magnitude (Malhi et al., 2011). Assuming a $\mathrm{C}$ concentration of $50 \%$ in above- and belowground litter inputs, this implies that roughly $900 \mathrm{~g} \mathrm{C} \mathrm{m}^{-2} \mathrm{yr}^{-1}$ are delivered to the soil via leaf and root litter. Modeled turnover times of the mineralassociated slow pool imply $\mathrm{C}$ inputs of $76-228 \mathrm{~g} \mathrm{C} \mathrm{m}^{-2} \mathrm{yr}^{-1}$ $\left(\right.$ mean $\left.=160 \mathrm{~g} \mathrm{C} \mathrm{m}^{-2} \mathrm{y}^{-1}\right)$ from 0 to $20 \mathrm{~cm}$ in each plot. Inputs of $\mathrm{C}$ to the mineral-associated slow pool thus represent a substantial C flux of approximately $10-25 \%$ of annual litter inputs in this forest. These are conservative estimates given that inputs to the mineral-associated slow fraction $\mathrm{C}$ below $20 \mathrm{~cm}$ depth are also likely to be important (Koarashi et al., 2012), especially in ridges and valleys, where the $0-10$ and $10-20 \mathrm{~cm}$ horizons did not differ in $\Delta{ }^{14} \mathrm{C}$ or $\mathrm{C}$ stocks.

\subsubsection{Erosion/deposition impacts on $\Delta^{14} \mathrm{C}$}

Erosion and deposition also represent potentially important fluxes of $\mathrm{C}$ in these soils over pedogenic timescales given their steep slopes and high precipitation, but erosion is unlikely to have an overriding impact on interpretations of decadal $\mathrm{C}$ turnover times in our sites. Other studies have shown $\Delta^{14} \mathrm{C}$ enrichment in toeslope positions corresponding with recent $\mathrm{C}$ inputs from upslope erosion (Berhe et al., 2012; Berhe and Kleber, 2013). In these studies, relatively small inputs of modern $\mathrm{C}$ had a large impact on soil $\Delta^{14} \mathrm{C}$ and inferred turnover times due to the predominance of pre-modern ${ }^{14} \mathrm{C}$ in these soils. In our study ecosystem, however, rapid cycling of the mineral-associated slow $\mathrm{C}$ pool led to significant bomb ${ }^{14} \mathrm{C}$ enrichment in all samples regardless of year sampled or topographic position. In this context, realistic inputs of $\mathrm{C}$ from erosion would have negligible impact on mineralassociated $\Delta^{14} \mathrm{C}$, given that erosive transport in this site is relatively minor in comparison with biological $\mathrm{C}$ fluxes over annual to decadal timescales. Lateral surface fluxes of fine litter and soil on slopes averaged $5 \pm 4$ and $9 \pm 6 \mathrm{~g} \mathrm{~m}^{-2} \mathrm{yr}^{-1}$ (masses of litter and soil, respectively) in sites located near our plots (Larsen et al., 1999). Even if erosion were 10fold greater at our site, the $\mathrm{C}$ fluxes would be negligible in comparison with litter inputs to the mineral-associated slow pool. We acknowledge that large episodic landslides impacting $>100 \mathrm{~m}^{2}$ can occur in this forest (Scatena and Lugo,
1995), although there is no evidence of major landslides at this site over the preceding decades. The low clay content of the riparian valley soils relative to ridges and slopes suggests that clay removal by irregular flood events exceeds clay deposition over pedogenic timescales. Thus, large-scale geomorphic processes such as landslides and floods shape this forest landscape over scales of centuries to millennia, but their impact on $\mathrm{C}$ dynamics of the mineral-associated slow pool has likely been minor at this particular site over at least the last several decades.

Nevertheless, fine-scale variation in geomorphic processes such as soil creep or tree tip-up mounds may be important in explaining variation in soil $\Delta^{14} \mathrm{C}$ among samples, particularly for the five samples with relatively lower $\Delta^{14} \mathrm{C}$ values. Relatively fewer ${ }^{14} \mathrm{C}$ studies have been conducted along hillslope catenas, which are likely to show greater spatial variability than soils formed on level terrain.

\subsection{Implications for models and global trends in mineral-associated $\mathrm{C}$ turnover}

The presence of archived soil samples was critical for constraining our models of mineral-associated $\mathrm{C}$ turnover, yet relatively few historical data sets have been analyzed for ${ }^{14} \mathrm{C}$. We are aware of only one such study conducted in humid tropical soils (Telles et al., 2003), although this approach has been applied more frequently in temperate soils (Trumbore et al., 1996; Baisden et al., 2002, 2013; Koarashi et al., 2012; Sierra et al., 2012; Schrumpf and Kaiser, 2015). Radiocarbon analysis of archived 1988 samples revealed that we could not usefully model the mineral-associated $\mathrm{C}$ fraction as a uniform pool with a single turnover time. Although the heterogeneous nature of mineral-associated $\mathrm{C}$ and the implications for modeling were noted almost two decades ago (Trumbore et al., 1995), many recent studies modeled the turnover of physically separated mineral-associated $\mathrm{C}$ fractions as uniform pools (Crow et al., 2007; Marin-Spiotta et al., 2008; Leifeld and Fuhrer, 2009; Meyer et al., 2012; McFarlane et al., 2013; Herold et al., 2014). Other studies have further separated mineral-associated $\mathrm{C}$ by additional density fractions or chemical treatment (Telles et al., 2003; Sollins et al., 2009; Giardina et al., 2014), but these fractions also likely represent mixtures of faster- and slower-cycling $\mathrm{C}$ pools that complicate interpretation of a single mean residence time. For example, Telles et al. (2003) found significant bomb ${ }^{14} \mathrm{C}$ in acid hydrolysis residue of a dense soil fraction. This finding illustrates that even $\mathrm{C}$ that is highly stable to chemical degradation can have a significant fast-cycling component, and thus cannot be usefully modeled as a uniform pool.

Using multiple ${ }^{14} \mathrm{C}$ measurements over time to mathematically model multiple $\mathrm{C}$ pools within a single density fraction provides a useful alternative to physically separating each pool of interest. Using an 11-point time series from a New Zealand grassland soil, Baisden et al. (2013) showed that a two-pool model could closely approximate bulk soil ${ }^{14} \mathrm{C} \mathrm{dy-}$ 
namics. Additional work showed that including a third pool of rapidly cycling (months-years) $\mathrm{C}$ was also useful (Baisden and Keller, 2013). However, in the present study we did not have access to additional data necessary to parameterize a third pool. Rather, to minimize the impact of very rapidly cycling $\mathrm{C}$ we removed particulate organic matter by density fractionation (Baisden and Canessa, 2013). Particulate organic matter typically decomposes over timescales of months in this ecosystem (Cusack et al., 2009) and thus has a significantly different isotope composition from mineralassociated $\mathrm{C}$ which would affect bulk soil $\Delta^{14} \mathrm{C}$ values even at low abundance. It is likely that mineral-associated $\mathrm{C}$ also contains a portion of very rapidly cycling $\mathrm{C}$, although this pool is inherently difficult to estimate with ${ }^{14} \mathrm{C}$ measurements (Baisden and Keller, 2013) and merits future study using other methods such as stable isotope labeling.

Our results confirm that single-pool turnover models of mineral-associated $\mathrm{C}$ can lead to misleading interpretations of turnover times and their relationship to $\Delta^{14} \mathrm{C}$, as recently summarized by Baisden and Canessa (2013). In our study, a one-pool model could not capture observed changes in $\Delta{ }^{14} \mathrm{C}$ between 1988 and 2012, and one- and two-pool models of mineral-associated $\mathrm{C}$ yielded contradictory relationships between ${ }^{14} \mathrm{C}$ and modeled mean residence times. Importantly, the one-pool model reversed the sign of the relationship between $\Delta{ }^{14} \mathrm{C}$ and turnover time, because a slow pool with decadal turnover times represented the majority of mineral-associated $\mathrm{C}$ in the two-pool model. Thus, relationships between $\mathrm{C}$ turnover and environmental drivers assessed using one-pool models of mineral-associated $\mathrm{C}$ can be qualitatively incorrect. Furthermore, the centennial turnover times of mineral-associated organic matter implied by many onepool models (Leifeld and Fuhrer, 2009; Meyer et al., 2012; McFarlane et al., 2013; Herold et al., 2014) obscure the finding from two-pool models that most mineral-associated $\mathrm{C}$ appears to cycle over decadal scales.

Accumulating evidence from studies employing paired ${ }^{14} \mathrm{C}$ analysis across a broad range of ecosystems and soil types suggests that most mineral-associated $\mathrm{C}$ in surface horizons cycles over scales of years to several decades and thus may respond more rapidly to ecosystem perturbations than previously thought. For example, residence times of a slow pool comprising $>70 \%$ of mineral-associated $\mathrm{C}$ varied between 10 and 40 years among samples spanning a 3million-year grassland chronosequence in California (Baisden et al., 2002). Similarly, $78-85 \%$ of total soil C (including a large portion of mineral-associated C) cycled over timescales of 9-17 years across New Zealand grassland soils varying in mineralogy (Baisden et al., 2013). Hydrolyzable $\mathrm{C}$ comprising the majority of mineral-associated $\mathrm{C}$ also cycled over decadal scales in surface soils across an elevation gradient in the Sierra Nevada of California (Trumbore et al., 1996). Subsoil mineral-associated organic matter in this region showed similar dynamics, where $28-73 \%$ of $\mathrm{C}$ had turnover times of 10-95 years (Koarashi et al., 2012). The slow-pool turnover times and abundances modeled in our study fall within this range, as do reported values from other humid tropical forests (Trumbore et al., 1995). In summary, these studies suggest that most mineral-associated $\mathrm{C}$ across a broad range of ecosystems cycles over decadal timescales, with little apparent relationship to differences in climate. Additional geographically distributed measurements of soil ${ }^{14} \mathrm{C}$ over time could provide insight into the impacts of ecosystem state factors on mineral-associated $\mathrm{C}$ turnover at a global scale.

\section{Conclusions}

Overall, we found that dynamics of mineral-associated soil C pools were remarkably similar across biogeochemically distinct soils spanning three taxonomic orders and two surface soil depths in a humid tropical forest, with $66 \%$ of this $\mathrm{C}$ cycling over timescales of approximately 18 years. Our results highlight the importance of dynamics of the mineralassociated slow pool in mediating surface soil responses to global change. Our data indicate that soil depths of at least $20 \mathrm{~cm}$ can be dominated by mineral-association $\mathrm{C}$ with decadal rather than centennial/millennial turnover times, and that large differences in soil biogeochemical properties such as texture, $\mathrm{pH}$, reactive metal content, root biomass, and bulk soil $\mathrm{O}_{2}$ do not necessarily have discernable impacts on decadal turnover rates. However, an index of reducing conditions (Fe(II) concentrations) at the scale of individual soil samples provided the best single predictor of $\Delta^{14} \mathrm{C}$, slowpool turnover, and $\mathrm{C}$ stocks, suggesting the influence of microsite redox conditions on $\mathrm{C}$ dynamics in these upland soils.

\section{The Supplement related to this article is available online at doi:10.5194/bg-12-2471-2015-supplement.}

Acknowledgements. All data summarized in this manuscript are available in the associated supplemental material. We thank H. Dang, J. Treffkorn, J. Cosgrove, R. Ryals, O. Gutierrez, A. McDowell, B. Ryals, and C. Torrens for crucial help in the field and lab. M. Firestone, R. Rhew, and the reviewers T. Baisden and J. Sanderman provided extremely valuable comments and discussion. S. J. Hall was funded by the DOE Office of Science Graduate Fellowship Program supported by the American Recovery and Reinvestment Act of 2009, administered by ORISE-ORAU under contract no. DE-AC05-06OR23100. Funding was also provided by NSF grant EAR-08199072 to W. L. Silver; the NSF Luquillo Critical Zone Observatory (EAR-0722476), with additional support provided by the USGS Luquillo WEBB program; and grant DEB 0620910 from NSF to the Institute for Tropical Ecosystem Studies, University of Puerto Rico, and to the International Institute of Tropical Forestry USDA Forest Service, as part of the Luquillo Long-Term Ecological Research Program. This work was supported by the USDA National Institute of Food and Agriculture, 
McIntire Stennis project CA-B-ECO-7673-MS.

Edited by: R. Bol

\section{References}

Baisden, W. T. and Canessa, S.: Using 50 years of soil radiocarbon data to identify optimal approaches for estimating soil carbon residence times, Nucl. Instrum. Meth. B, 294, 588-592, 2013.

Baisden, W. T. and Keller, E. D.: Synthetic constraint of soil C dynamics using 50 years of ${ }^{14} \mathrm{C}$ and net primary production (NPP) in a New Zealand grassland site, Radiocarbon, 55, 1071-1076, 2013.

Baisden, W. T., Amundson, R., Cook, A. C., and Brenner, D. L.: Turnover and storage of $\mathrm{C}$ and $\mathrm{N}$ in five density fractions from California annual grassland surface soils, Global Biogeochem. Cy., 16, 1117, doi:10.1029/2001GB001822, 2002.

Baisden, W. T., Parfitt, R. L., Ross, C., Schipper, L. A., and Canessa, S.: Evaluating 50 years of time-series soil radiocarbon data: towards routine calculation of robust $\mathrm{C}$ residence times, Biogeochemistry, 112, 129-137, 2013.

Baldock, J. A. and Skjemstad, J. O.: Role of the soil matrix and minerals in protecting natural organic materials against biological attack, Org. Geochem., 31, 697-710, 2000.

Berhe, A. A., Harden, J. W., Torn, M. S., Kleber, M., Burton, S. D., and Harte, J.: Persistence of soil organic matter in eroding versus depositional landform positions, J. Geophys. Res., 117, G02019, doi:10.1029/2011JG001790, 2012.

Berhe, A. A. and Kleber, M.: Erosion, deposition, and the persistence of soil organic matter: mechanistic considerations and problems with terminology, Earth Surf. Proc. Land., 38, 908912, 2013

Crow, S. E., Swanston, C. W., Lajtha, K., Brooks, J. R., and Keirstead, H.: Density fractionation of forest soils: methodological questions and interpretation of incubation results and turnover time in an ecosystem context, Biogeochemistry, 85, 6990, 2007.

Cusack, D. F., Chou, W. W., Yang, W. H., Harmon, M. E. and Silver, W. L.: Controls on long-term root and leaf litter decomposition in neotropical forests, Global Change Biol., 15, 1339-1355, 2009.

Cusack, D. F., Silver, W. L., Torn, M. S., and McDowell, W. H.: Effects of nitrogen additions on above- and belowground carbon dynamics in two tropical forests, Biogeochemistry, 104, 203225, 2011

de Camargo, P. B., Trumbore, S. E., Martinelli, L. A., Davidson, E. A., Nepstad, D. C., and Victoria, R. L.: Soil carbon dynamics in regrowing forest of eastern Amazonia, Global Change Biol., 5, 693-702, 1999.

Dubinsky, E. A., Silver, W. L., and Firestone, M. K.: Tropical forest soil microbial communities couple iron and carbon biogeochemistry, Ecology, 91, 2604-2612, 2010.

Ehleringer, J. R., Buchmann, N., and Flanagan, L. B.: Carbon isotope ratios in belowground carbon cycle processes, Ecol. Appl., $10,412-422,2000$.

Feller, C. and Beare, M. H.: Physical control of soil organic matter dynamics in the tropics, Geoderma, 79, 69-116, 1997.

Gaudinski, J. B., Trumbore, S. E., Davidson, E. A., and Zheng, S.: Soil carbon cycling in a temperate forest: radiocarbon-based es- timates of residence times, sequestration rates and partitioning of fluxes, Biogeochemistry, 51, 33-69, 2000.

Gee, G. and Bauder, J.: Particle size analysis, in: Methods of Soil Analysis, Part 1, Physical and Mineralogical Methods, edited by: Klute, A., J. Am. Soc. Agron., 383-411, Madison, WI, USA, 1986.

Giardina, C. P., Litton, C. M., Crow, S. E., and Asner, G. P. Warming-related increases in soil $\mathrm{CO}_{2}$ efflux are explained by increased below-ground carbon flux, Nature Clim. Change, 4, 822-827, 2014.

Gonzalez, G., Huang, C. Y., Zou, X., and Rodríguez, C.: Earthworm invasions in the tropics, Biol. Invasions, 8, 1247-1256, 2006.

Hall, S. J., McDowell, W. H., and Silver, W. L.: When wet gets wetter: Decoupling of moisture, redox biogeochemistry, and greenhouse gas fluxes in a humid tropical forest soil, Ecosystems, 16, 576-589, 2013.

Heartsill Scalley, T., Scatena, F. N., Lugo, A. E., Moya, S., and Estrada Ruiz, C. R.: Changes in structure, composition, and nutrients during $15 \mathrm{yr}$ of hurricane-induced succession in a subtropical wet forest in Puerto Rico, Biotropica, 42, 455-463, 2010.

Herold, N., Schöning, I., Michalzik, B., Trumbore, S., and Schrumpf, M.: Controls on soil carbon storage and turnover in German landscapes, Biogeochemistry, 119, 435-451, 2014.

Hua, Q., Barbetti, M., and Rakowski, A. Z.: Atmospheric radiocarbon for the period 1950-2010, Radiocarbon, 55, 2059-2072, 2013.

Jobbagy, E. G. and Jackson, R. B.: The vertical distribution of soil organic carbon and its relation to climate and vegetation, Ecol. Appl., 10, 423-436, 2000.

Kleber, M., Mikutta, R., Torn, M. S., and Jahn, R.: Poorly crystalline mineral phases protect organic matter in acid subsoil horizons, Eur. J. Soil Sci., 56, 717-725, 2005.

Koarashi, J., Hockaday, W. C., Masiello, C. A., and Trumbore, S. E.: Dynamics of decadally cycling carbon in subsurface soils, J. Geophys. Res., 117, G03033, doi:10.1029/2012JG002034, 2012.

Kramer, M. G., Sanderman, J., Chadwick, O. A., Chorover, J., and Vitousek, P. M.: Long-term carbon storage through retention of dissolved aromatic acids by reactive particles in soil, Global Change Biol., 18, 2594-2605, 2012.

Larsen, M. C., Torres-Sánchez, A. J., and Concepción, I. M.: Slopewash, surface runoff and fine-litter transport in forest and landslide scars in humid-tropical steeplands, Luquillo Experimental Forest, Puerto Rico, Earth Surf. Proc. Land., 24, 481-502, 1999.

Leifeld, J. and Fuhrer, J.: Long-term management effects on soil organic matter in two cold, high-elevation grasslands: clues from fractionation and radiocarbon dating, Eur. J. Soil Sci., 60, 230 239, 2009.

Liptzin, D., Silver, W. L., and Detto, M.: Temporal dynamics in soil oxygen and greenhouse gases in two humid tropical forests, Ecosystems, 14, 171-182, 2011.

Malhi, Y., Doughty, C., and Galbraith, D.: The allocation of ecosystem net primary productivity in tropical forests, Philos. T. Roy. Soc. B, 366, 3225-3245, 2011.

Marin-Spiotta, E., Swanston, C. W., Torn, M. S., Silver, W. L., and Burton, S. D.: Chemical and mineral control of soil carbon turnover in abandoned tropical pastures, Geoderma, 143, 49-62, 2008 . 
Marin-Spiotta, E., Silver, W. L., Swanston, C. W., and Ostertag, R.: Soil organic matter dynamics during 80 years of reforestation of tropical pastures, Global Change Biol., 15, 1584-1597, 2009.

Masiello, C. A., Chadwick, O. A., Southon, J., Torn, M. S., and Harden, J. W.: Weathering controls on mechanisms of carbon storage in grassland soils, Global Biogeochem. Cy., 18, GB4023, doi:10.1029/2004GB002219, 2004.

McDowell, W. H., Scatena, F. N., Waide, R. B., Brokaw, N., Camilo, G., Covich, A., Crowl, T., Gonzalez, G., Greathouse, E., Klawinski, P., Lodge, D., Lugo, A., Pringle, C., Richardson, B., Richardson, M., Schaefer, D., Silver, W., Thompson, J., Vogt, D., Vogt, K., Willig, M., Woolbright, L., Zou, X., and Zimmerman, J.: Geographic and ecological setting of the Luquillo Mountains, in: A Caribbean Forest Tapestry: The Multidimensional Nature of Disturbance and Response, edited by: Brokaw, N., Crowl, T., Lugo, A., McDowell, W. H., Scatena, F. N., Waide, R. B., and Willig, M., 72-163, Oxford University Press, New York, USA, 2012.

McFarlane, K. J., Torn, M. S., Hanson, P. J., Porras, R. C., Swanston, C. W., Callaham, M. A., and Guilderson, T. P.: Comparison of soil organic matter dynamics at five temperate deciduous forests with physical fractionation and radiocarbon measurements, Biogeochemistry, 112, 457-476, 2013.

Meyer, S., Leifeld, J., Bahn, M., and Fuhrer, J.: Free and protected soil organic carbon dynamics respond differently to abandonment of mountain grassland, Biogeosciences, 9, 853-865, doi:10.5194/bg-9-853-2012, 2012.

Phillips, E. J. P., Lovley, D. R., and Roden, E. E.: Composition of non-microbially reducible Fe(III) in aquatic sediments, Appl. Environ. Microb., 59, 2727-2729, 1993.

Pinheiro, J., Bates, D., DebRoy, S., Sarkar, D., and R Core Development Team: nlme: Linear and Nonlinear Mixed Effects Models, available at: http://CRAN.R-project.org/package=nlme, last access: 1 June 2014.

Ponnamperuma, F. N.: The chemistry of submerged soils, Adv. Agron., 24, 29-96, 1972.

Powers, J. S. and Schlesinger, W. H.: Relationships among soil carbon distributions and biophysical factors at nested spatial scales in rain forests of northeastern Costa Rica, Geoderma, 109, 165190, 2002

Powers, J. S., Montgomery, R. A., Adair, E. C., Brearley, F. Q., DeWalt, S. J., Castanho, C. T., Chave, J., Deinert, E., Ganzhorn, J. U., Gilbert, M. E., González-Iturbe, J. A., Bunyavejchewin, S., Grau, H. R., Harms, K. E., Hiremath, A., Iriarte-Vivar, S., Manzane, E., De Oliveira, A. A., Poorter, L., Ramanamanjato, J.-B., Salk, C., Varela, A., Weiblen, G. D., and Lerdau, M. T.: Decomposition in tropical forests: a pan-tropical study of the effects of litter type, litter placement and mesofaunal exclusion across a precipitation gradient, J. Ecol., 97, 801-811, 2009.

Rasse, D. P., Rumpel, C., and Dignac, M.-F.: Is soil carbon mostly root carbon? Mechanisms for a specific stabilisation, Plant Soil, 269, 341-356, 2005.

Reyes, I. and Torrent, J.: Citrate-ascorbate as a highly selective extractant for poorly crystalline iron oxides, Soil Sci. Soc. Am. J., 61, 1647-1654, 1997.

Saini, G. R.: Organic matter as a measure of bulk density of soil, Nature, 210, 1295-1296, 1966.

Scatena, F. N. and Lugo, A. E.: Geomorphology, disturbance, and the soil and vegetation of two subtropical wet steepland watersheds of Puerto Rico, Geomorphology, 13, 199-213, 1995.
Scatena, F. N., Moya, S., Estrada, C., and Chinea, J. D.: The first five years in the reorganization of aboveground biomass and nutrient use following Hurricane Hugo in the Bisley Experimental Watersheds, Luquillo Experimental Forest, Puerto Rico, Biotropica, 28, 424-440, 1996.

Schrumpf, M. and Kaiser, K.: Large differences in estimates of soil organic carbon turnover in density fractions by using single and repeated radiocarbon inventories, Geoderma, 239-240, 168-178, 2015.

Schuur, E. A. G., Chadwick, O. A., and Matson, P. A.: Carbon cycling and soil carbon storage in mesic to wet Hawaiian montane forests, Ecology, 82, 3182-3196, 2001.

Sexstone, A., Revsbech, N., Parkin, T., and Tiedje, J.: Direct measurement of oxygen profiles and denitrification rates in soil aggregates, Soil Sci. Soc. Am. J., 49, 645-651, 1985.

Sierra, C. A., Trumbore, S. E., Davidson, E. A., Frey, S. D., Savage, K. E., and Hopkins, F. M.: Predicting decadal trends and transient responses of radiocarbon storage and fluxes in a temperate forest soil, Biogeosciences, 9, 3013-3028, doi:10.5194/bg-9-30132012, 2012.

Silver, W. L. and Vogt, K. A.: Fine-root dynamics following single and multiple disturbances in a subtropical wet forest ecosystem, J. Ecol., 81, 729-738, 1993.

Silver, W. L., Scatena, F. N., Johnson, A. H., Siccama, T. G., and Sanchez, M. J.: Nutrient availability in a montane wet tropical forest - Spatial patterns and methodological considerations, Plant Soil, 164, 129-145, 1994.

Silver, W. L., Lugo, A. E., and Keller, M.: Soil oxygen availability and biogeochemistry along rainfall and topographic gradients in upland wet tropical forest soils, Biogeochemistry, 44, 301-328, 1999.

Soil Survey Staff: Soil survey of Caribbean National Forest and Luquillo Experimental Forest, Commonwealth of Puerto Rico, United States Department of Agriculture, Natural Resources Conservation Service, Washington, DC, USA, 2002.

Sollins, P., Kramer, M. G., Swanston, C., Lajtha, K., Filley, T., Aufdenkampe, A. K., Wagai, R., and Bowden, R. D.: Sequential density fractionation across soils of contrasting mineralogy: evidence for both microbial- and mineral-controlled soil organic matter stabilization, Biogeochemistry, 96, 209-231, 2009.

Stuiver, M. and Polach, H. A.: Discussion: reporting of ${ }^{14} \mathrm{C}$ data, Radiocarbon, 19, 355-363, 1977.

Stuiver, M., Reimer, P. J., and Braziunas, T. F.: High-precision radiocarbon age calibration for terrestrial and marine samples, Radiocarbon, 40, 1127-1151, 1998.

Swanston, C. W., Torn, M. S., Hanson, P. J., Southon, J. R., Garten, C. T., Hanlon, E. M., and Ganio, L.: Initial characterization of processes of soil carbon stabilization using forest stand-level radiocarbon enrichment, Geoderma, 128, 52-62, 2005.

Teh, Y. A., Silver, W. L., and Scatena, F. N.: A decade of belowground reorganization following multiple disturbances in a subtropical wet forest, Plant Soil, 323, 197-212, 2009.

Telles, E. de C. C., de Camargo, P. B., Martinelli, L. A., Trumbore, S. E., da Costa, E. S., Santos, J., Higuchi, N., and Oliveira, R. C.: Influence of soil texture on carbon dynamics and storage potential in tropical forest soils of Amazonia, Global Biogeochem. Cy., 17, 1040, doi:10.1029/2002GB001953, 2003. 
Thompson, A., Chadwick, O. A., Boman, S., and Chorover, J.: Colloid mobilization during soil iron redox oscillations, Environ. Sci. Technol., 40, 5743-5749, 2006.

Thompson, A., Rancourt, D., Chadwick, O., and Chorover, J.: Iron solid-phase differentiation along a redox gradient in basaltic soils, Geochim. Cosmochim. Ac., 75, 119-133, 2011.

Torn, M. S., Trumbore, S. E., Chadwick, O. A., Vitousek, P. M., and Hendricks, D. M.: Mineral control of soil organic carbon storage and turnover, Nature, 389, 170-173, 1997.

Torn, M. S., Vitousek, P. M., and Trumbore, S. E.: The influence of nutrient availability on soil organic matter turnover estimated by incubations and radiocarbon modeling, Ecosystems, 8, 352-372, 2005.

Torn, M. S., Swanston, C. W., Castanha, C., and Trumbore, S. E.: Storage and turnover of organic matter in soil, in BiophysicoChemical Processes Involving Natural Nonliving Organic Matter, in: Environmental Systems, edited by: Senesi, N., Xing, B., and Huang, P. M., 219-227, John Wiley \& Sons Inc., Hoboken, NJ, USA, 2009.

Torn, M. S., Kleber, M., Zavaleta, E. S., Zhu, B., Field, C. B., and Trumbore, S. E.: A dual isotope approach to isolate soil carbon pools of different turnover times, Biogeosciences, 10, 80678081, doi:10.5194/bg-10-8067-2013, 2013.
Townsend, A. R., Vitousek, P. M., and Trumbore, S. E.: Soil organic matter dynamics along gradients in temperature and land use on the island of Hawaii, Ecology, 76, 721-733, 1995.

Trumbore, S. E.: Comparison of carbon dynamics in tropical and temperate soils using radiocarbon measurements, Global Biogeochem. Сy., 7, 275-290, 1993.

Trumbore, S. E., Davidson, E. A., de Camargo, P. B., Nepstad, D. C., and Martinelli, L. A.: Belowground cycling of carbon in forests and pastures of eastern Amazonia, Global Biogeochem. Cy., 9, 515-528, 1995.

Trumbore, S. E., Chadwick, O. A., and Amundson, R.: Rapid exchange between soil carbon and atmospheric carbon dioxide driven by temperature change, Science, 272, 393-396, 1996.

Vargas, R., Trumbore, S. E., and Allen, M. F.: Evidence of old carbon used to grow new fine roots in a tropical forest, New Phytol., 182, 710-718, 2009.

Viollier, E., Inglett, P., Hunter, K., Roychoudhury, A., and van Cappellen, P.: The ferrozine method revisited: $\mathrm{Fe}(\mathrm{II}) / \mathrm{Fe}(\mathrm{III})$ determination in natural waters, Appl. Geochem., 15, 785-790, 2000.

Von Lützow, M., Kögel-Knabner, I., Ekschmitt, K., Flessa, H., Guggenberger, G., Matzner, E., and Marschner, B.: SOM fractionation methods: Relevance to functional pools and to stabilization mechanisms, Soil Biol. Biochem., 39, 2183-2207, 2007. 